\title{
An investigation into overheating in social housing dwellings in central England
}

Johanna Morey $^{* a}$, Arash Beizaee ${ }^{\mathrm{a} \dagger}$, Andrew Wright ${ }^{\mathrm{a}}$

${ }^{a}$ Institute of Energy and Sustainable Development, De Montfort University, Leicester, Leics., LE1 9BH, UK

†Present Address: School of Architecture, Building and Civil Engineering, Loughborough University, Loughborough, Leics., LE11 3TU, UK

*Corresponding author: johannam3446@gmail.com

Keywords: Summer temperature, Thermal comfort, Overheating, Social housing, English homes, Monitoring

\begin{abstract}
Recent empirical studies have evidenced overheating in UK dwellings during hotter periods. Vulnerable people living in social housing dwellings may be less able to tolerate heat stress or to adapt. This study is the first large scale monitoring study to investigate overheating risk in social housing dwellings in central England against three overheating risk assessment criteria. Indoor temperature data for summer 2015 were analysed for 122 freerunning social housing properties, of varying type and age, against the Chartered Institution of Building Services Engineers (CIBSE) static guidance, and the adaptive methods of TM52 and TM59. The mean bedroom and living room temperatures were $21.2^{\circ} \mathrm{C}$ and $21.7^{\circ} \mathrm{C}$, respectively. Bedrooms were more likely to overheat than living rooms using the static criteria, with $42 \%$ of bedrooms exceeding $5 \%$ of occupied hours over $24^{\circ} \mathrm{C}$, and $40 \%$ exceeding $1 \%$ of occupied hours over $26^{\circ} \mathrm{C} .24 \%$ of living rooms exceeded $5 \%$ of occupied hours over $25^{\circ} \mathrm{C}$, and $5 \%$ exceeded $1 \%$ of occupied hours over $28^{\circ} \mathrm{C}$. Against TM52, only $1 \%$ of bedrooms and $2 \%$ of living rooms overheated. Against TM59, 5\% of bedrooms and 1\% of living rooms overheated. Analysis by various property categories identified those types of property which were more prone to overheating.
\end{abstract}

\section{Introduction}

In recent years, investigations into the internal temperatures of English dwellings have highlighted their potential to overheat (DCLG, 2012), (Pathan et al., 2017), (Lomas \& Porritt, 2017), (Beizaee et al., 2013). This is

\footnotetext{
Abbreviations: ASHRAE, American Society of Heating, Refrigeration and Air Conditioning; $\mathrm{Cl}$, confidence interval; CIBSE, Chartered Institution of Building Services Engineers; CVRMSE, Coefficient of Variation of the Root Mean Squared Error; EHS, English Housing Survey; EPC, Energy Performance Certificate; NMBE, Normalised Mean Bias Error; $R^{2}$, Coefficient of Determination; SAP, Standard Assessment Procedure; SD, Standard deviation; TM, Technical Memorandum.
} 
of concern due to the potential adverse health effects at higher temperatures; it is estimated that heatwaves during summer 2018 were responsible for 863 excess mortalities, with the over 65 age group particularly affected (PHE, 2018). With a view to improving energy efficiency during cooler periods, modern homes are built to increasingly higher standards of insulation, as required by The Building Regulations (HM Government 2016) and this, along with building characteristics and occupant behaviour, may increase the likelihood of overheating.

Social housing in England consists of dwellings owned by local authorities or housing associations. In 2018, there were four million social housing properties in England, accounting for 17\% of all dwellings (MHCLG, 2019a). Age, illness and limiting health conditions have been cited as risk factors for heat mortalities (DCLG, 2012), and social housing accommodates occupant groups which may be particularly vulnerable to heat. Within the social rental sector, $54 \%$ of households contain an occupant with a long-term illness or disability compared with $31 \%$ for owner occupiers and $23 \%$ for private rentals (MHCLG, $2019 \mathrm{~b}$ ). $27 \%$ of occupants in the social rental sector are aged 65 and over compared to $8 \%$ of private rentals, and although this is lower than the $36 \%$ of owner occupier, this is still a significant proportion (ibid.).

Monitoring offers absolute temperature measurements for occupied conditions, however, studies focusing on social housing in the UK are few and involve relatively small numbers of properties (Vellei et al., 2017), (Tabatabaei Sameni et al., 2015), (Mavrogianni et al., 2015). Vellei et al. (2017) compared overheating between vulnerable and non-vulnerable households within a survey of 55 social housing properties in Exeter, south west England. The static criterion of $1 \%$ of occupied hours over $26^{\circ} \mathrm{C}$ was exceeded in 15 out of 18 (83\%) bedrooms during the summer of 2014 and four out of 16 (25\%) bedrooms during the cooler summer of 2015. Against the TM52 adaptive method (Section 2.5), two out of 41 (5\%) living rooms failed and no living rooms failed during the summer of 2015. Rooms inhabited by vulnerable occupants were found to be more likely to overheat than those with non-vulnerable occupants, attributed to a lack of ventilation and the heating being turned on within the summer period. Tabatabaei Sameni et al. (2015) studied living rooms from 25 social housing flats located in Coventry during three periods within the summers of 2011, 2012 and 2013. The flats were built to the Passivhaus standard and based on the Passivhaus exceedance limit of $10 \%$ of annual occupied hours over $25^{\circ} \mathrm{C}$, it was deemed that 18 of the flats were at risk of overheating, with occupant behaviour an important factor. Upon application of the TM52 adaptive method, 11 properties failed. 
Studies beyond those of social housing provide further information on the extent of overheating for various property types. Seven recent UK monitoring studies with reasonably large sample sizes are summarised in Table 1 as concerns mean room temperatures and performance against CIBSE based static overheating thresholds (including the social housing study of Vellei et al. (2017)). The criteria are often exceeded by a high percentage of properties, particularly in bedrooms. Differences between studies may be expected due to different locations, weather conditions, sample sizes and types of properties, as well as different monitoring periods and assumptions concerning occupied hours. Where annual data are not available, exceedance may relate to occupied hours for the monitored period (Beizaee et al., 2013), (Lomas \& Kane, 2013), or an assumption made that overheating will only occur during summer months (Pathan et al., 2017). Lomas and Porritt (2017) present a review of recent empirical overheating studies in the UK and summarise that high insulation and lightweight construction are contributing to increasing summertime overheating. Other UK overheating monitoring studies include the investigation of flats in northern England (Baborska-Narożny et al., 2017) and in London (Mavrogianni et al., 2015), new builds in Scotland (Morgan et al., 2017), a Passivhaus bungalow in northern England, (Fletcher et al., 2017), and two timber frame builds in south-east England (Adekunle \& Nikolopoulou, 2016). Experimentally, Tink et al. (2018) investigated the effect of insulation on overheating in conjunction with solar shading and night ventilation schemes.

In addition to empirical studies, dynamic thermal simulation allows the investigation of the effect of various property characteristics on internal temperatures, e.g. built form, building orientation, building fabric materials, solar shading, ventilation and occupancy behaviour (Porritt et al., 2012), (Taylor et. al., 2014), (van Hooff et al., 2015), (Symonds et al., 2017), (Mavrogianni et al., 2012, 2017), (Fosas et al., 2018). Simulation studies also enable the prediction of internal temperatures in response to various future climate scenarios (Peacock et al., 2010), (Oikonomou et al., 2012), (Taylor et. al., 2014), (Lee \& Steemers, 2017), (Gupta \& Gregg,2018), (Hamdy et al., 2017).

This paper presents the results from the largest survey of summertime temperatures and overheating risk in social housing dwellings in the UK to date. The study aims to investigate the extent of summertime overheating in social housing dwellings in central England and to identify the types of properties most likely to be affected. Living room and bedroom temperature data from 122 monitored housing association properties located in and around the Midlands, UK were analysed for summer 2015. Overheating in living rooms and bedrooms were 
assessed against CIBSE static as well as TM52 and TM59 adaptive overheating criteria. Statistical significance tests were carried out to evaluate the relationship between overheating risk and various factors, including property type, Standard Assessment Procedure (SAP) rating (DECC, 2012), year of build, wall construction and built form.

Table 1 Summary of UK temperature monitoring studies since 2013 reporting mean room temperatures and/or exceedance above static criteria. Outdoor means are quoted where readily available/calculable. Where an adaptive method was also used, this is stated.

\begin{tabular}{|c|c|c|c|c|c|c|c|c|c|c|c|}
\hline \multirow[t]{2}{*}{ Authors } & \multirow[t]{2}{*}{$\begin{array}{l}\text { Sample } \\
\text { size }\end{array}$} & \multirow[t]{2}{*}{ Period } & \multirow{2}{*}{$\begin{array}{l}\text { Outdoor } \\
\text { Mean } \\
\text { Temp } \\
{ }^{\circ} \mathrm{C} \\
\end{array}$} & \multirow[t]{2}{*}{ Location } & \multicolumn{3}{|l|}{ Bedroom } & \multicolumn{3}{|c|}{ Living Room } & \multirow[t]{2}{*}{$\begin{array}{l}\text { Adaptive } \\
\text { Criteria }\end{array}$} \\
\hline & & & & & $\begin{array}{l}\text { Percentage } \\
\text { exceedanc } \\
24^{\circ} \mathrm{C}(5 \%)\end{array}$ & $26^{\circ} \mathrm{C}(1 \%)$ & $\begin{array}{l}\text { Mean } \\
\text { Temp } \\
{ }^{\circ} \mathrm{C}\end{array}$ & $\begin{array}{l}\text { Percentage } \\
\text { exceedanc } \\
25^{\circ} \mathrm{C}(5 \%)\end{array}$ & $28^{\circ} \mathrm{C}(1 \%)$ & $\begin{array}{l}\text { Mean } \\
\text { Temp } \\
{ }^{\circ} \mathrm{C}\end{array}$ & \\
\hline $\begin{array}{l}\text { Pathan et } \\
\text { al. (2017) }\end{array}$ & $\begin{array}{l}91 \\
\text { (Living } \\
\text { room) } \\
94 \\
\text { (Bedroom) }\end{array}$ & $\begin{array}{l}\text { Summer } \\
2009\end{array}$ & 17.5 & $\begin{array}{l}\text { London } \\
\text { Exceedance: } \\
\text { Annual } \\
\text { hours }\end{array}$ & $81 \%$ & $33 \%$ & - & $13 \%$ & $6 \%$ & - & $\begin{array}{l}\text { ASHRAE } \\
\text { Standard } \\
55\end{array}$ \\
\hline $\begin{array}{l}\text { Pathan et } \\
\text { al. (2017) }\end{array}$ & $\begin{array}{l}91 \\
\text { (Living } \\
\text { room) } \\
93 \\
\text { (Bedroom) } \\
\end{array}$ & $\begin{array}{l}\text { Summer } \\
2010\end{array}$ & 17.5 & $\begin{array}{l}\text { London } \\
\text { Exceedance: } \\
\text { Annual } \\
\text { hours }\end{array}$ & $89 \%$ & $67 \%$ & - & $25 \%$ & $15 \%$ & - & $\begin{array}{l}\text { ASHRAE } \\
\text { Standard } \\
55\end{array}$ \\
\hline $\begin{array}{l}\text { Beizaee et } \\
\text { al. (2013) }\end{array}$ & 193 & $\begin{array}{l}\text { July } 22 \text { - } \\
\text { August } 31 \\
2007\end{array}$ & 15.3 & $\begin{array}{l}\text { England } \\
\text { Exceedance: } \\
\text { Period } \\
\text { hours }\end{array}$ & $47 \%$ & $21 \%$ & 21.6 & $27 \%$ & $4 \%$ & 21.8 & $\begin{array}{l}\text { BSEN } \\
15251\end{array}$ \\
\hline $\begin{array}{l}\text { Lomas \& } \\
\text { Kane } \\
(2013)\end{array}$ & 230 & $\begin{array}{l}\text { July - } \\
\text { August } \\
2009\end{array}$ & 16.4 & $\begin{array}{l}\text { Leicester } \\
\text { Exceedance: } \\
\text { Period } \\
\text { hours }\end{array}$ & $92 \%$ & $88 \%$ & 22.4 & $58 \%$ & $27 \%$ & 22.2 & $\begin{array}{l}\text { BSEN } \\
15251\end{array}$ \\
\hline $\begin{array}{l}\text { McGill et } \\
\text { al. } \\
\text { (2017) }\end{array}$ & $\begin{array}{l}53 \\
\text { (Living } \\
\text { room) } \\
55 \\
\text { (Bedroom) }\end{array}$ & $\begin{array}{l}2012 \text { - } \\
2014 \\
\text { August } \\
2013 \text { (for } \\
\text { means) }\end{array}$ & - & $\begin{array}{l}\text { UK } \\
\text { New builds/ } \\
\text { some MVHR } \\
\text { Exceedance: } \\
\text { Annual } \\
\text { hours }\end{array}$ & - & $62 \%$ & 23.8 & $75 \%$ & $25 \%$ & 24.0 & TM52 \\
\hline $\begin{array}{l}\text { Mavrogian- } \\
\text { ni et al. } \\
\text { (2017) }\end{array}$ & 101 & $\begin{array}{l}\text { August } \\
2009\end{array}$ & - & London & - & - & 23.4 & - & - & 23.1 & - \\
\hline $\begin{array}{l}\text { DECC } \\
(2013) \\
\end{array}$ & 823 & $\begin{array}{l}\text { Summer } \\
2011\end{array}$ & - & England & - & - & 21.5 & - & - & 21.2 & - \\
\hline $\begin{array}{l}\text { Vellei et al. } \\
\text { (2017) }\end{array}$ & $\begin{array}{l}18 \\
\text { (Bedroom) }\end{array}$ & $\begin{array}{l}\text { Summer } \\
2014\end{array}$ & 15.8 & Exeter & - & $83 \%$ & & - & - & - & TM52 \\
\hline $\begin{array}{l}\text { Vellei et al. } \\
\text { (2017) }\end{array}$ & $\begin{array}{l}16 \\
\text { (Bedroom) }\end{array}$ & $\begin{array}{l}\text { Summer } \\
2015\end{array}$ & 14.8 & Exeter & - & $25 \%$ & & - & - & - & TM52 \\
\hline
\end{tabular}

\section{Methodology}

A temperature monitoring survey of housing association domestic properties was conducted by EMH homes, primarily with a view to the assessment of energy efficiency during the heating season. The study presented here focuses on the investigation of overheating for 122 properties during summer 2015 (June $1^{\text {st }}-$ August $31^{\text {st }}$ ) when buildings were free-running and the effects of property characteristics on internal temperatures could be examined without the additional variable of heating. The properties were predominantly located in and around the Midlands region of the UK (Figure 1). 


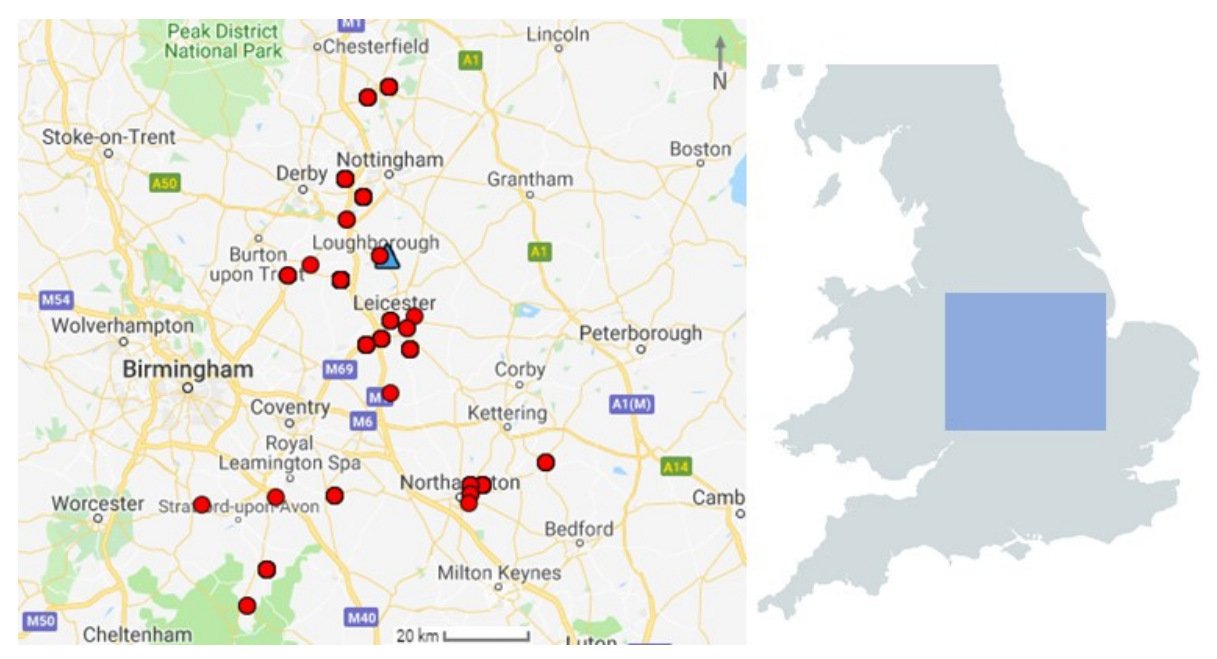

Figure 1 Location of properties in the final data set within the UK. Dots represent one or more properties by postcode district. Triangle shows the location of Sutton Bonington weather station which provided the external weather data used in this study. Source: Google Maps, Map data (2019 Google

\subsection{Sample composition}

The initial data set containing raw half-hourly temperature data from 151 properties underwent a data cleaning procedure (Section 2.4), resulting in a final data set of 122 properties. The composition of the final data set is given in Figures 2 and 3 where it is compared with the 2017 English Housing Survey (EHS) for the whole of England by type and by build period (MHCLG, 2019c). The EMH homes data set has a lower proportion of flats, a higher proportion of bungalows, a lower proportion of earlier period builds and a higher proportion of later builds than the EHS social housing survey, but is otherwise deemed a fairly representative sample of English social housing properties.

Property selection was governed by the desire to include a wide range of archetypes and by the willingness of tenants to participate in the study. EMH homes provided details on room type, property type, SAP rating, year of build, wall construction, flat level and built form. This information came from in-house records and surveyor assessment. Energy Performance Certificate (EPC) assessments were performed by in-house qualified staff during the study. SAP ratings, ranging from A to G, are based on EPC points (ranging from 0 to 100 with a higher value associated with a better energy performance) which are assigned to a property according to its overall energy performance, with ' $A$ ' rated properties the best performers (MHCLG, 2019a). The average number of EPC points for the final data set of properties with a known rating was 68, higher than the average of 62 for English dwellings and equal to the English social housing average (ibid.). These ratings correspond to the SAP band D. When compared with the EHS SAP ratings for English dwellings (Table 2), those EMH final data set properties 
with a known rating are representative of the distribution for English social rentals, albeit with a higher percentage of $\mathrm{B}$ rated properties. There were no $\mathrm{A}$ rated properties in the final data set.

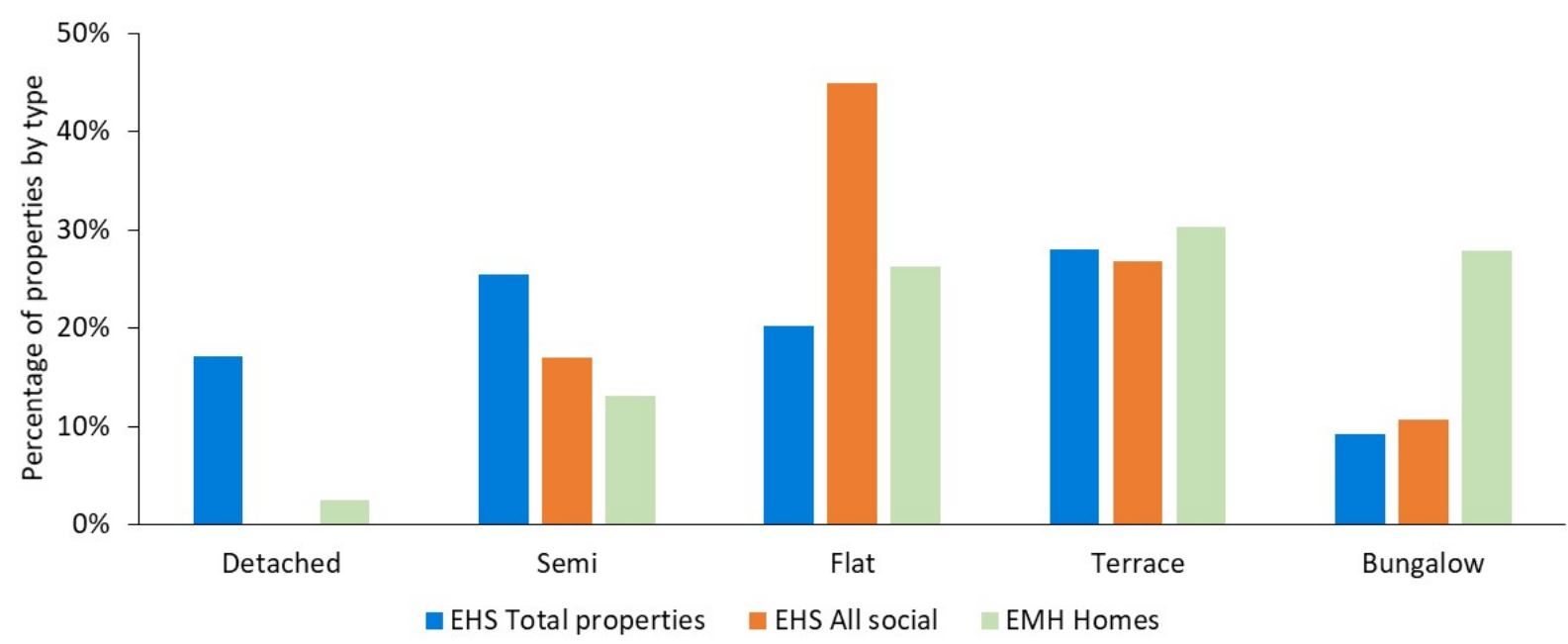

Figure 2 Composition of EMH final data set by property type compared with English Housing Survey (MHCLG, 2019c)

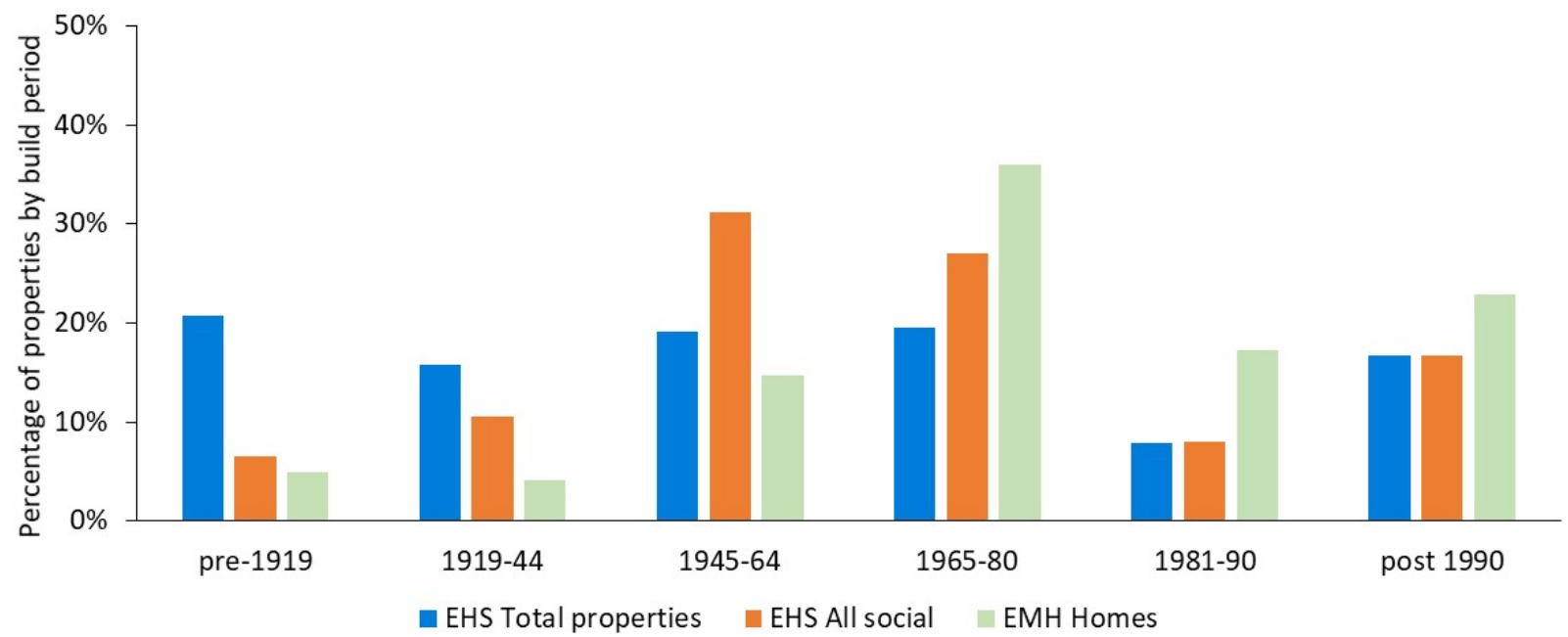

Figure 3 Composition of EMH final data set by build period compared with English Housing Survey (MHCLG, 2019c)

Table 2 SAP ratings for the final data set compared with 2017 English Housing Survey (MHCLG, 2019a)

Final data set

\begin{tabular}{cccc}
\hline SAP rating & $\begin{array}{c}\text { Number of } \\
\text { properties }\end{array}$ & $\begin{array}{c}\text { \% of all } \\
\text { properties }\end{array}$ & $\begin{array}{c}\text { \% of 'known } \\
\text { rating' properties }\end{array}$ \\
\hline No rating & 30 & $24.6 \%$ & \\
A & 0 & $0.0 \%$ & $0.0 \%$ \\
B & 7 & $5.7 \%$ & $7.6 \%$ \\
C & 42 & $34.4 \%$ & $45.7 \%$ \\
D & 34 & $27.9 \%$ & $37.0 \%$ \\
E & 8 & $6.6 \%$ & $8.7 \%$ \\
F & 1 & $0.8 \%$ & $1.1 \%$ \\
G & 0 & $0.0 \%$ & $0.0 \%$
\end{tabular}

\begin{tabular}{ccc} 
EHS 2017 & & \\
\hline $\begin{array}{c}\text { SAP } \\
\text { rating }\end{array}$ & $\begin{array}{c}\text { Social } \\
\text { rentals }\end{array}$ & $\begin{array}{c}\text { All } \\
\text { tenures }\end{array}$ \\
\hline & & \\
& & \\
A/B & $2.2 \%$ & $1.3 \%$ \\
C & $50.0 \%$ & $28.8 \%$ \\
D & $41.3 \%$ & $50.5 \%$ \\
E & $5.2 \%$ & $14.4 \%$ \\
F & $0.9 \%$ & $3.8 \%$ \\
G & $0.4 \%$ & $1.2 \%$
\end{tabular}




\subsection{External weather data collection}

All property postcodes lay within 60 miles of the Sutton Bonington weather station (Latitude: 52.836, Longitude: -1.250). Sutton Bonington was the station nearest to most properties which supplied both hourly dry bulb temperature and global irradiance measurements, and these were obtained from the MIDAS datasets (Met Office, 2006a), (Met Office, 2006b). The monitoring period of $1^{\text {st }}$ June to $31^{\text {st }}$ August 2015 represents a typical summer, being only slightly cooler than average when compared with 1981 to 2010 average values for England as a whole and for the Midlands region, and with similar total hours of sunshine as shown in Table 3.

Table 3 Average maximum, average minimum and mean temperatures $\left({ }^{\circ} \mathrm{C}\right)$ with total hours of sunshine for summer 2015 (June to August) compared with 1981 to 2010 summer average values (Met Office, 2019a), (Met Office 2006a)

\begin{tabular}{lcccc} 
Region & Average maximum & Average minimum & Mean & Total hours sunshine \\
\hline England 2015 & 19.9 & 10.6 & 15.2 & 565 \\
England 1981-2010 & 20.1 & 11.0 & 15.5 & 561 \\
Midlands 2015 & 20.0 & 10.4 & 15.2 & 555 \\
Midlands 1981-2010 & 20.3 & 10.8 & 15.5 & 543 \\
Sutton Bonington 2015 & 20.3 & 10.7 & 15.6 & $546^{\dagger}$
\end{tabular}

${ }^{\dagger}$ From daily weather data containing two "Not Available" values (Met Office, 2019b). These were replaced with the daily average for the summer (5.9 hours).

Figure 4 presents hourly air temperature and global irradiance during the monitoring period which is obtained from Sutton Bonington weather station. 


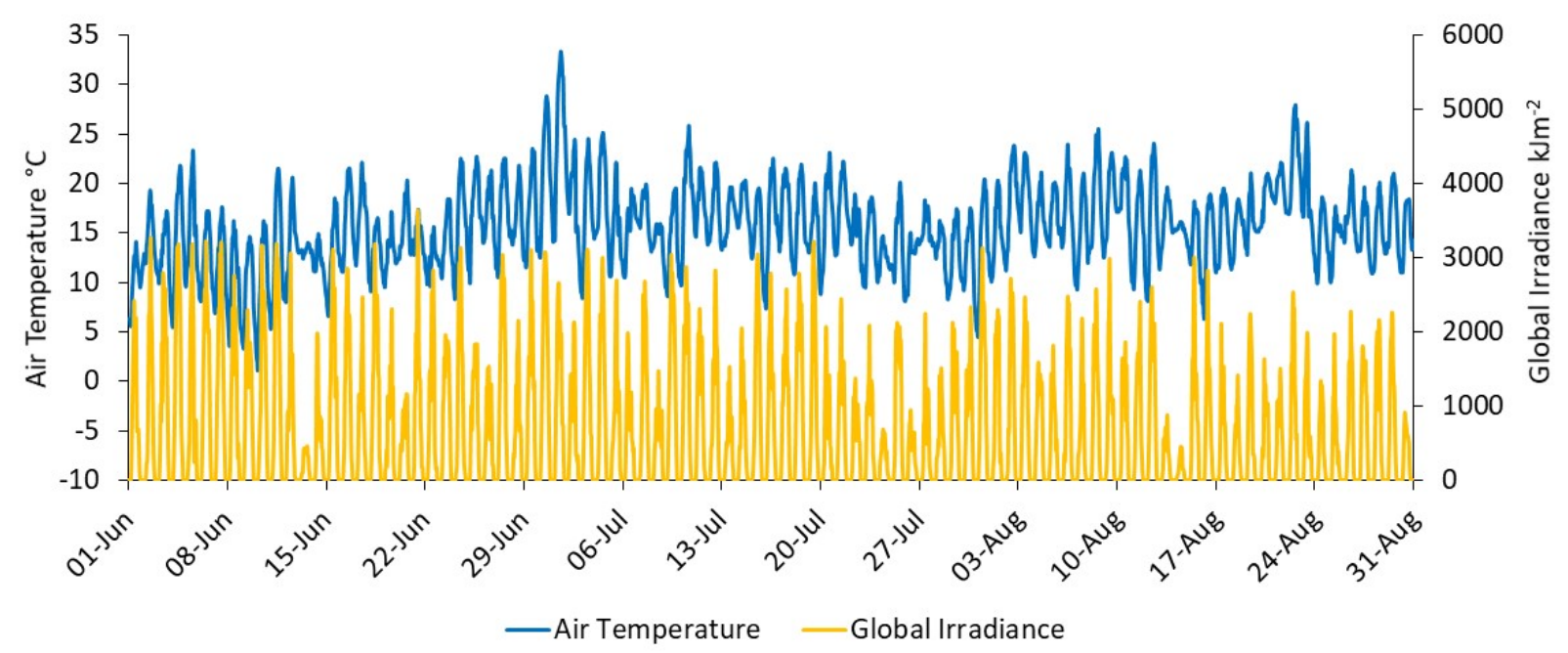

Figure 4 Weather data for summer 2015 (Sutton Bonington weather station): Air temperature ${ }^{\circ} \mathrm{C}$ (dry bulb) and global irradiance $\mathrm{kJm}^{-2}$

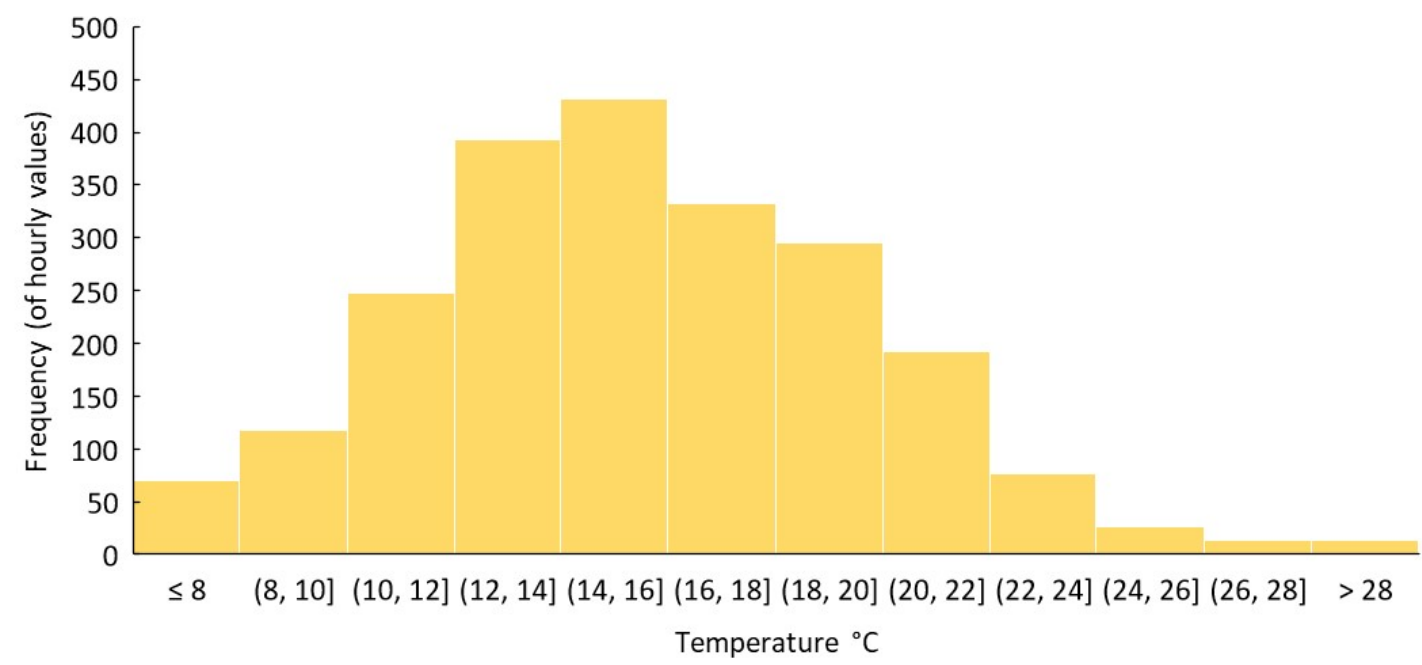

Figure 5 Histogram of hourly air temperature values (dry bulb) for summer 2015 (Sutton Bonington weather station)

For summer 2015 , the maximum air temperature measured at the Sutton Bonington weather station was $33.3^{\circ} \mathrm{C}$ on July $1^{\text {st }}$ at 1500 hours. The minimum temperature of $1.1^{\circ} \mathrm{C}$ occurred on June $10^{\text {th }}$ at 0400 hours, and the mean temperature was $15.6^{\circ} \mathrm{C}$. Temperatures exceeded $20^{\circ} \mathrm{C}$ for 321 hours (15\%), and $22^{\circ} \mathrm{C}$ for 129 hours (6\%). Figure 5 gives a histogram of hourly air temperature values. There was a two-day hot spell from June $30^{\text {th }}$ to July $1^{\text {st }}$ with maximum temperatures of $28.8^{\circ} \mathrm{C}$ and $33.3^{\circ} \mathrm{C}$ reached on June $30^{\text {th }}$ and July $1^{\text {st }}$, respectively, although the night-time temperature on July $1^{\text {st }}$ dropped to $14.1^{\circ} \mathrm{C}$.

\subsection{Indoor temperature data collection and data checking}

Indoor air temperature data were provided by EMH homes. An Orsis CO2SS Combined Temperature, Humidity and $\mathrm{CO}_{2}$ Sensor, with an accuracy of $\pm 1^{\circ} \mathrm{C}$ and range of $-25^{\circ} \mathrm{C}$ to $+55^{\circ} \mathrm{C}$ (Orsis, 2019), was placed in each living 
room and in the main bedroom per property. Sensors were typically placed upon shelves away from any sources of heat, draught and direct sun exposure by a trained team from the EMH homes. However, extra checks were carried out by the authors to assess and ensure the reliability of sensor data. Two properties, EMH52 and EMH56, were randomly selected and monitored using calibrated HOBO sensors pendant sensors (UA-001-01) with an accuracy of $\pm 0.53^{\circ} \mathrm{C}$ and a range of $-25^{\circ} \mathrm{C}$ to $+70^{\circ} \mathrm{C}$ (Onset, 2019). The temperature reliability assessment was conducted for around 16 weeks from the March $1^{\text {st }}$ to June $21^{\text {st }} 2017$. For each room, one HOBO sensor was positioned next to the existing Orsis sensor, and another HOBO sensor was positioned at the mid height in the volumetric centre of the room. The Normalised Mean Bias Error (NMBE) and Coefficient of Variation of the Root Mean Squared Error (CVRMSE) were calculated (ASHRAE, 2002) ${ }^{1}$. All calculations were performed using measurements at hourly intervals ${ }^{2}$. The mean and maximum (magnitude) percentages for NMBE were $2.1 \%$ and $4.9 \%$, respectively. The mean and maximum percentages for CVRMSE were $3.8 \%$, and $6.1 \%$, respectively. For the purpose of calibrating building energy simulation models, ASHRAE Guideline 14 advises accuracies of below +/10\% for NMBE, and less than 30\% for CVRMSE for hourly data (ASHRAE, 2002). The NMBE and CVRMSE values for the sensor calibration exercise lie well within these limits ensuring that the accuracy of measurements by Orsis sensors were significantly higher than a calibrated dynamic building energy model. Where the HOBO sensor was positioned next to the Orsis sensor, $R^{2}$ values, i.e. the Coefficient of Determination $\left(R^{2}\right)$ for the linear regression of the Orsis readings against the НОВО readings, were above 0.96 , and, where the НОВO sensor was positioned at mid room height, $\mathrm{R}^{2}$ values were above 0.90 . From the correlation between HOBO and Orsis sensors, along with the NMBE and CVRMSE results, it is concluded that the Orsis sensors provided a reasonable measurement of room temperature for the study.

\subsection{Data cleaning}

Initial data cleaning was performed using R version 3.5.1 (The R Foundation, 2018). Raw half-hourly temperature data from 151 properties (132 bedrooms and 142 living rooms) entered the cleaning process and were sampled

$$
\begin{aligned}
& { }^{1} N M B E=\frac{\sum_{i=1}^{N i}(M i-S i)}{\sum_{i=1}^{N i} M i} \\
& C V R M S E=\frac{\sqrt{\sum_{i=1}^{N i}\left[\frac{(M i-S i)^{2}}{N i}\right]}}{\frac{1}{N i} \sum_{i=1}^{N i} M i}
\end{aligned}
$$

$\mathrm{M}_{\mathrm{i}}$ and $\mathrm{S}_{\mathrm{i}}$ refer to Orsis and $\mathrm{HOBO}$ measurements, respectively, $\mathrm{N}_{\mathrm{i}}$ is the number of readings

${ }^{2}$ For the living room of EMH52, 21.5\% of the Orsis data over the 16-week period was missing; the results quoted are for the remaining data. Additionally, the bedroom mid height HOBO sensor for EMH52 went missing before data was able to be retrieved. 
at hourly values to match weather data intervals. Properties with more than $4 \%$ missing or erroneous (i.e. negative) reading values were removed ${ }^{3}$. Missing or erroneous data with run lengths of four hours and under were replaced with linearly interpolated values, those with a greater run length were omitted to avoid misrepresentation of internal temperature variation. This resulted in 103 bedrooms and 104 living rooms with cleaned, linearly interpolated data from a total of 122 homes. Internal temperature plots for each room were then visually inspected in conjunction with delta lag, external temperature and solar irradiance plots to identify any potential heating periods as well as highlight sensor issues, such as step changes or noise. Here, delta lag is defined as the change in temperature between subsequent hourly temperature readings;

$$
\text { Delta lag }=T_{\text {int }}(t)-T_{\text {int }}(t-1 \text { hour })
$$

where $T_{\text {int }}(t)$ is the internal temperature at time $t$, and $T_{\text {int }}(t-1$ hour $)$ is the internal temperature one hour before time t.

The delta lag trace of Figure 6 for EMH100 is a typical plot with most values lying well within $\pm 1^{\circ} \mathrm{C}$ and no prominent spikes evident. The increase in delta lag magnitude at the start of July was apparent in many traces and corresponds to a short period of hotter external temperatures.

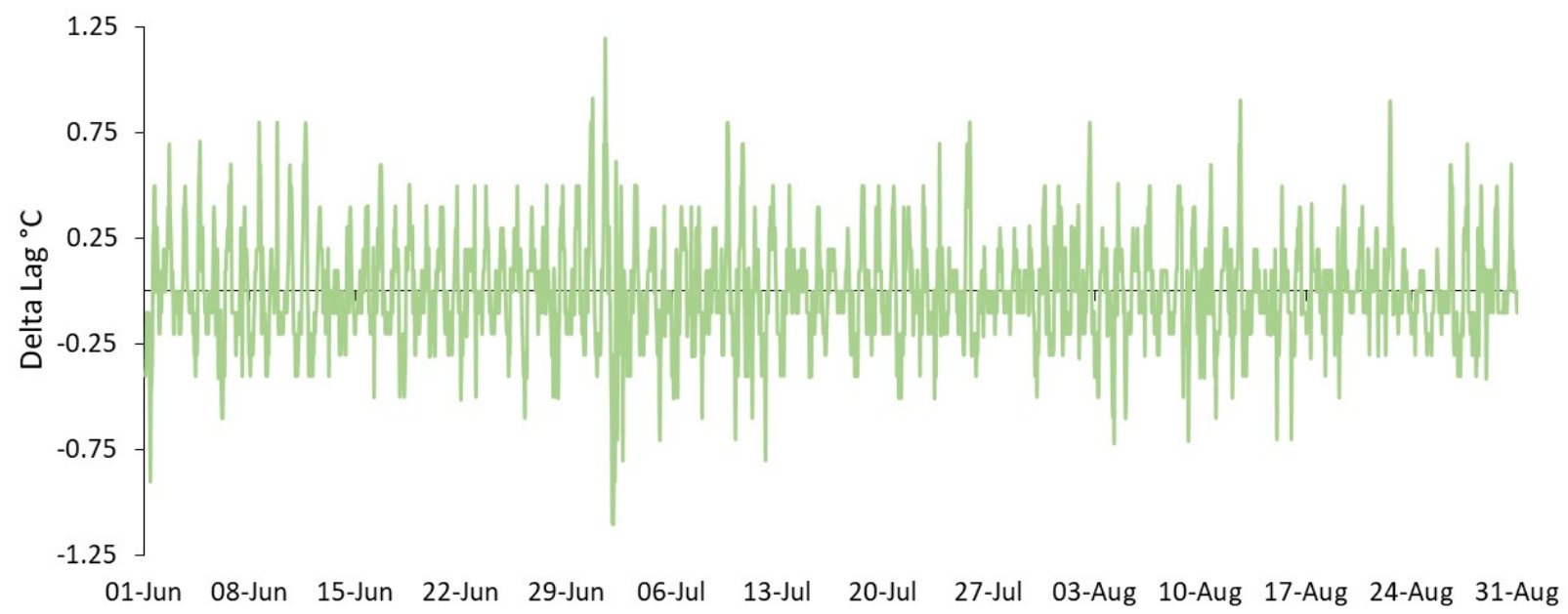

Figure 6 EMH100 (Bedroom) Delta lag, summer 2015. A typical trace.

Four bedrooms and four living rooms were removed from the data set due to obvious periods of change in the delta lag traces which did not correspond to changes in the global irradiance and external air temperature data.

\footnotetext{
${ }^{3}$ With a $3 \%$ limit for erroneous or missing records, 1 bedroom and 4 living rooms would be additionally removed when compared with the $4 \%$ cut off; with a $5 \%$ limit, 1 bedroom and 2 living rooms would be added. It is thought that a $4 \%$ limit is reasonable in view of a balance between retaining properties and the completeness of data for any particular room.
} 
The delta lag traces for one of the rejected living rooms, EMH4, is given in Figure 7. Here there are distinctive, prolonged parts of the trace with a change in the magnitude of the general fluctuation indicating a step change in conditions or sensor position. Additionally, one bedroom was removed from the data set due to a distinctive internal temperature trace with some periodicity associated with a, typically, $2^{\circ} \mathrm{C}$ to $3{ }^{\circ} \mathrm{C}$ rise in temperature which did not always correspond to solar irradiance or daylight hours, suggesting room heating or that the sensor was affected by internal gains.

The final data set (post visual inspection) contained 98 bedrooms and 100 living rooms from a total of 122 properties. 76 properties had data for both rooms, 22 had data for bedroom only, and 24 had data for living room only.

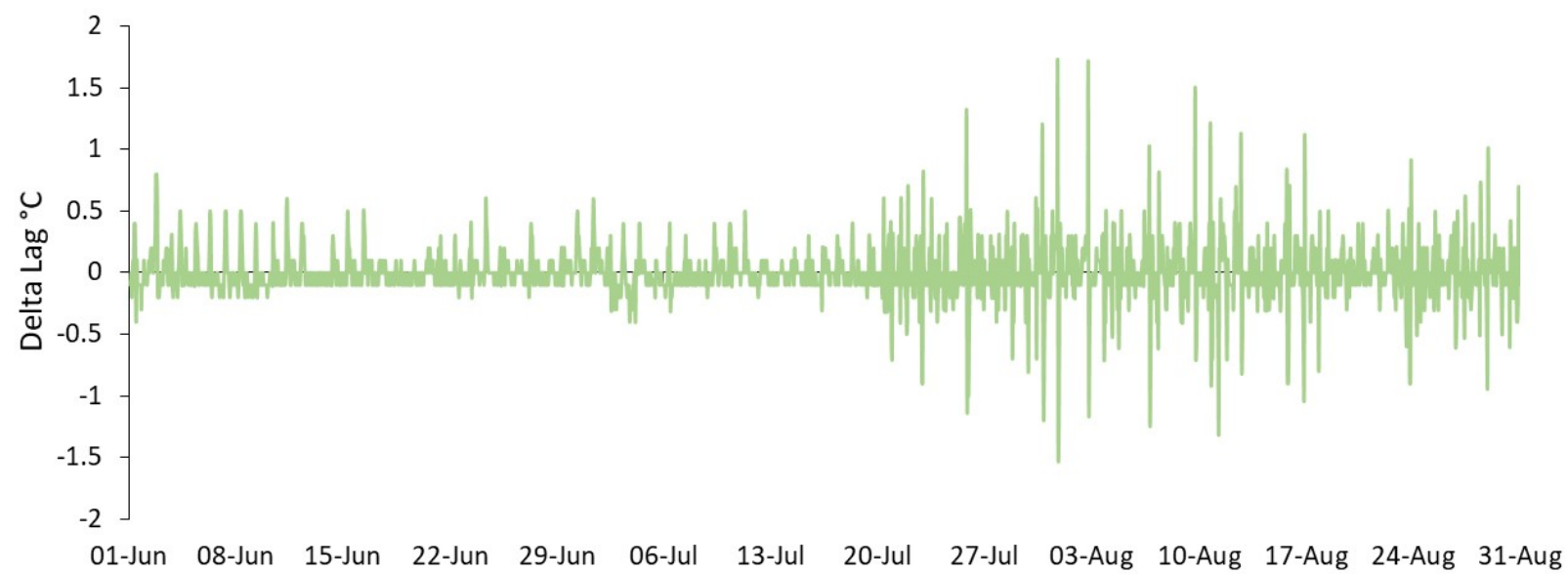

Figure 7: EMH4 (Living room) Delta lag trace for a rejected room.

\subsection{Statistical analysis}

Statistical analysis was performed using (The R Foundation, 2018). Within each category (property type, SAP rating, year of build, wall construction, flat level and built form), the mean of all the hourly values for each property was first determined before calculation of the summary statistics. A Welch Two Sample t-test, selected for its applicability to samples of different sizes and unequal variances, was used to compare pairs of mean values from Table 4 (Section 3.1) belonging to the same category, with the exception of wall construction due to the high proportion of filled cavities. The whole analysis was repeated for values from Table 5 (Section 3.1). Results significant at the $p<0.1$ and $p<0.05$ levels are shown in Table A.1 (Appendix). 


\subsection{Assessment of overheating}

Living rooms were assessed against $5 \%$ of occupied hours over $25^{\circ} \mathrm{C}$ and $1 \%$ of occupied hours over $28^{\circ} \mathrm{C}$, and bedrooms were assessed against $5 \%$ of occupied hours over $24^{\circ} \mathrm{C}$ and $1 \%$ of occupied hours over $26^{\circ} \mathrm{C}$, as employed by other studies (Table 1). These static criteria are based upon historic and current CIBSE guidance (CIBSE, 2015), (CIBSE, 2017). Assessment was also made against the adaptive thermal comfort standard of Technical Memorandum TM52 (CIBSE, 2013) where two out of three criteria are required to fail for a property to fail overall. Criterion 1 limits the number of hours where the comfort threshold temperature, $T_{\max }{ }^{4}$, is exceeded by at least $1 \mathrm{~K}$ for not more than $3 \%$ of occupied hours during May to September inclusive ${ }^{5}$. Criterion 2 sets a limit on the exceedance of the comfort threshold temperature within any one day. Criterion 3 sets an absolute maximum temperature for the room, which is $4 \mathrm{~K}$ above the comfort threshold temperature. Additionally, assessment was made using Criteria (a) and (b) from Technical Memorandum TM59 which relates to overheating in dwellings rather than being focused on the workplace (CIBSE, 2017). Criterion (a) is identical to Criterion 1 of TM52. Criterion (b) applies to bedrooms only and states that the operative temperature from 2200 to 0700 hours should not exceed $26^{\circ} \mathrm{C}$ for more than $1 \%$ of annual hours ${ }^{6}$.

\subsection{Occupied hours}

For statistical analysis and assessment of overheating, occupied hours were assumed to be 0800 to 2200 hours inclusive for living rooms and 2300 to 0700 hours inclusive for bedrooms, applied for both weekdays and weekends; these hours were chosen as being fairly representative of other studies (Lomas \& Kane, 2013), (Beizaee et al., 2013), (McGill et al., 2017). The exception was TM59 Criteria (b) where bedrooms were assessed against $1 \%$ of projected annual occupied hours over $26^{\circ} \mathrm{C}$ and occupied hours were 2200 to 0700 hours inclusive.

\footnotetext{
${ }^{4} \mathrm{~T}_{\max }=0.33 \mathrm{~T}_{\mathrm{rm}}+21.8$ where $\mathrm{T}_{\mathrm{rm}}$ is the exponentially weighted running mean for the external temperature $\left({ }^{\circ} \mathrm{C}\right)$ approximated as $T_{r m}=(1-\alpha) T_{\text {ext }}-1+\alpha . T_{r m}-1$. $T_{\text {ext }}-1$ is the daily mean external temperature for the previous day. $\alpha$ is a constant value; $(\alpha=0.8)$ is used here, as recommended by CIBSE.

${ }^{5}$ This is different to the June $1^{\text {st }}$ to August $31^{\text {st }}$ period used for the current study where no overheating was assumed for the months May and September.

${ }^{6}$ The current study assumes that overheating does not occur outside June $1^{\text {st }}$ to August $31^{\text {st }}$.
} 


\section{Results}

\subsection{Summary statistics}

Summary statistics for summer 2015 are given in Tables 4 and 5 for the 98 bedrooms and 100 living rooms of the final data set.

Table 4 Bedroom temperature summary statistics by category for occupied hours ${ }^{7}$. Temperatures in ${ }^{\circ} \mathrm{C}, \mathrm{n}=$ sample size.

\begin{tabular}{|c|c|c|c|c|c|c|c|}
\hline BEDROOM & $\mathbf{n}$ & Mean & $95 \%$ C I & SD & Median & Min & Max \\
\hline ALL PROPERTIES & 98 & 21.2 & $(20.9,21.5)$ & 1.4 & 21.3 & 17.7 & 24.5 \\
\hline \multicolumn{8}{|l|}{ PROPERTY TYPE } \\
\hline House & 45 & 21.5 & $(21.0,21.9)$ & 1.4 & 21.6 & 18.4 & 24.5 \\
\hline Bungalow & 27 & 20.8 & $(20.2,21.3)$ & 1.4 & 20.7 & 17.7 & 23.5 \\
\hline Flat & 26 & 21.2 & $(20.6,21.8)$ & 1.5 & 21.1 & 18.8 & 24.3 \\
\hline \multicolumn{8}{|l|}{ SAP RATING } \\
\hline B & 4 & 22.9 & $(20.0,25.7)$ & 1.8 & 23.3 & 20.4 & 24.5 \\
\hline C & 34 & 21.3 & $(20.9,21.8)$ & 1.4 & 21.3 & 18.8 & 24.4 \\
\hline D & 29 & 20.9 & $(20.4,21.5)$ & 1.5 & 21.0 & 17.7 & 23.5 \\
\hline$E$ & 7 & 20.4 & $(19.4,21.5)$ & 1.1 & 19.9 & 18.8 & 21.7 \\
\hline $\mathrm{F}$ & 1 & 21.8 & NA & NA & NA & NA & NA \\
\hline No SAP rating & 23 & 21.3 & $(20.7,21.8)$ & 1.2 & 21.3 & 19.0 & 23.4 \\
\hline \multicolumn{8}{|l|}{ YEAR OF BUILD } \\
\hline pre 1966 & 22 & 21.3 & $(20.7,21.9)$ & 1.4 & 21.3 & 18.9 & 24.3 \\
\hline $1966-1981$ & 36 & 20.5 & $(20.1,20.9)$ & 1.3 & 20.4 & 17.7 & 23.2 \\
\hline 1982- 1995 & 29 & 21.6 & $(21.1,22.1)$ & 1.3 & 21.6 & 18.8 & 24.4 \\
\hline post 1995 & 11 & 22.3 & $(21.5,23.0)$ & 1.1 & 22.2 & 20.6 & 24.5 \\
\hline \multicolumn{8}{|c|}{ WALL CONSTRUCTION } \\
\hline Filled cavity & 84 & 21.2 & $(20.9,21.5)$ & 1.5 & 21.1 & 17.7 & 24.5 \\
\hline Unfilled cavity & 7 & 21.0 & $(19.9,22.1)$ & 1.2 & 21.0 & 19.5 & 22.4 \\
\hline Solid - Uninsulated & 2 & 21.0 & $(6.3,35.7)$ & 1.6 & 21.0 & 19.9 & 22.2 \\
\hline Solid - Insulated & 5 & 22.0 & $(21.3,22.7)$ & 0.6 & 21.9 & 21.3 & 22.7 \\
\hline \multicolumn{8}{|l|}{ FLAT LEVEL } \\
\hline Ground floor & 14 & 20.7 & $(20.0,21.5)$ & 1.3 & 20.5 & 18.8 & 22.7 \\
\hline Mid floor & 6 & 22.1 & $(20.7,23.4)$ & 1.3 & 22.5 & 20.4 & 23.4 \\
\hline Top floor & 6 & 21.6 & $(19.7,23.5)$ & 1.8 & 21.5 & 18.8 & 24.3 \\
\hline \multicolumn{8}{|c|}{ BUILT FORM (Houses \& Bungalows) } \\
\hline Detached & 3 & 20.7 & $(15.1,26.3)$ & 2.2 & 20.0 & 18.8 & 23.2 \\
\hline End terrace & 18 & 21.6 & $(20.8,22.4)$ & 1.6 & 21.6 & 18.4 & 24.5 \\
\hline Mid terrace & 18 & 21.1 & $(20.5,21.7)$ & 1.2 & 21.0 & 19.1 & 23.5 \\
\hline Semi detached & 29 & 21.1 & $(20.6,21.6)$ & 1.3 & 21.5 & 17.7 & 23.0 \\
\hline
\end{tabular}

\footnotetext{
${ }^{7}$ Calculations for Tables 4 and 5 use the individual property means within each category, e.g. "Mean" refers to the average of the individual property means, and "Max" refers to the maximum of the individual property means.
} 
${ }^{\dagger}$ Other 4

${ }^{\dagger}$ 'Other' refers to mid terrace properties with 3 stories, mid terrace properties with an offset, or terrace properties with an unknown position

Table 5 Living room summary statistics by category for occupied hours, calculated using the individual property means within each category. Temperatures in ${ }^{\circ} \mathrm{C}, \mathrm{n}=$ sample size.

\begin{tabular}{|c|c|c|c|c|c|c|c|}
\hline LIVING ROOM & $\mathbf{n}$ & Mean & $95 \% \mathrm{Cl}$ & SD & Median & Min & Max \\
\hline ALL PROPERTIES & 100 & 21.7 & $(21.4,22.0)$ & 1.5 & 21.5 & 17.7 & 24.8 \\
\hline \multicolumn{8}{|l|}{ PROPERTY TYPE } \\
\hline House & 42 & 21.4 & $(21.0,21.9)$ & 1.5 & 21.1 & 18.5 & 24.8 \\
\hline Bungalow & 32 & 21.7 & $(21.2,22.2)$ & 1.5 & 21.8 & 17.8 & 24.3 \\
\hline Flat & 26 & 22.0 & $(21.4,22.7)$ & 1.6 & 21.9 & 17.7 & 24.4 \\
\hline \multicolumn{8}{|l|}{ SAP RATING } \\
\hline B & 6 & 22.7 & $(21.1,24.4)$ & 1.6 & 22.4 & 21.0 & 24.8 \\
\hline C & 36 & 21.7 & $(21.1,22.2)$ & 1.6 & 21.7 & 17.7 & 24.4 \\
\hline D & 28 & 21.2 & $(20.6,21.7)$ & 1.3 & 21.1 & 17.8 & 23.8 \\
\hline E & 6 & 22.0 & $(20.9,23.1)$ & 1.0 & 22.4 & 20.5 & 23.0 \\
\hline $\mathrm{F}$ & 1 & 22.7 & NA & NA & NA & NA & NA \\
\hline No SAP rating & 23 & 22.0 & $(21.3,22.7)$ & 1.6 & 21.5 & 19.1 & 24.8 \\
\hline \multicolumn{8}{|l|}{ YEAR OF BUILD } \\
\hline pre 1966 & 22 & 21.3 & $(20.7,21.9)$ & 1.4 & 21.3 & 18.9 & 24.4 \\
\hline $1966-1981$ & 37 & 21.2 & $(20.6,21.7)$ & 1.6 & 21.2 & 17.7 & 24.8 \\
\hline 1982- 1995 & 26 & 22.2 & $(21.7,22.7)$ & 1.2 & 22.3 & 19.5 & 24.4 \\
\hline post 1995 & 15 & 22.5 & $(21.7,23.3)$ & 1.5 & 22.5 & 20.4 & 24.8 \\
\hline \multicolumn{8}{|c|}{ WALL CONSTRUCTION } \\
\hline Filled cavity & 85 & 21.6 & $(21.3,22.0)$ & 1.5 & 21.5 & 17.7 & 24.4 \\
\hline Unfilled cavity & 8 & 21.5 & $(19.9,23.1)$ & 1.9 & 20.1 & 19.1 & 24.4 \\
\hline Solid - Uninsulated & 2 & 22.1 & $(20.7,23.6)$ & 0.2 & 22.1 & 22.0 & 22.3 \\
\hline Solid - Insulated & 4 & 22.0 & $(18.9,25.2)$ & 2.0 & 21.6 & 20.2 & 24.8 \\
\hline Timber frame & 1 & 24.8 & NA & NA & NA & NA & NA \\
\hline \multicolumn{8}{|l|}{ FLAT LEVEL } \\
\hline Ground floor & 13 & 21.5 & $(20.4,22.6$ & 1.9 & 21.3 & 17.7 & 24.4 \\
\hline Mid floor & 5 & 23.2 & $(22.2,24.3)$ & 0.8 & 23.3 & 21.9 & 24.0 \\
\hline Top floor & 8 & 22.1 & $(21.0,23.2)$ & 1.3 & 21.9 & 20.1 & 24.2 \\
\hline \multicolumn{8}{|c|}{ BUILT FORM (Houses \& Bungalows) } \\
\hline Detached & 4 & 20.6 & $(18.3,23.0)$ & 1.5 & 20.4 & 19.1 & 22.6 \\
\hline End terrace & 17 & 22.4 & $(21.6,23.2)$ & 1.5 & 22.4 & 19.3 & 24.8 \\
\hline Mid terrace & 17 & 21.0 & $(20.3,21.8)$ & 1.4 & 20.8 & 18.5 & 24.4 \\
\hline Semi detached & 33 & 21.6 & $(21.1,22.1)$ & 1.4 & 21.5 & 17.8 & 24.3 \\
\hline${ }^{\dagger}$ Other & 3 & & & & & & \\
\hline
\end{tabular}




\subsection{Overheating against static criteria}

Tables A.2 and A.3 of the Appendix give the number of properties which exceeded the various static criteria for summer 2015. For each category variable, Pearson's chi-square test of independence with Yates' continuity correction was performed to ascertain whether the category results were significant within the category. The $F$ rated property was not included in the SAP category analysis, nor the timber frame property in the wall construction category analysis due to the sample sizes of one. Rooms in dwellings without a SAP rating were not included in the SAP category analysis. Figures 8 and 9 depict the percentage occupied hours above the threshold temperatures by property for bedroom and living room, respectively. Figures 10 to 13 display the percentage of occupied hours per property above the lower temperature criteria for each room by SAP rating and year of build.

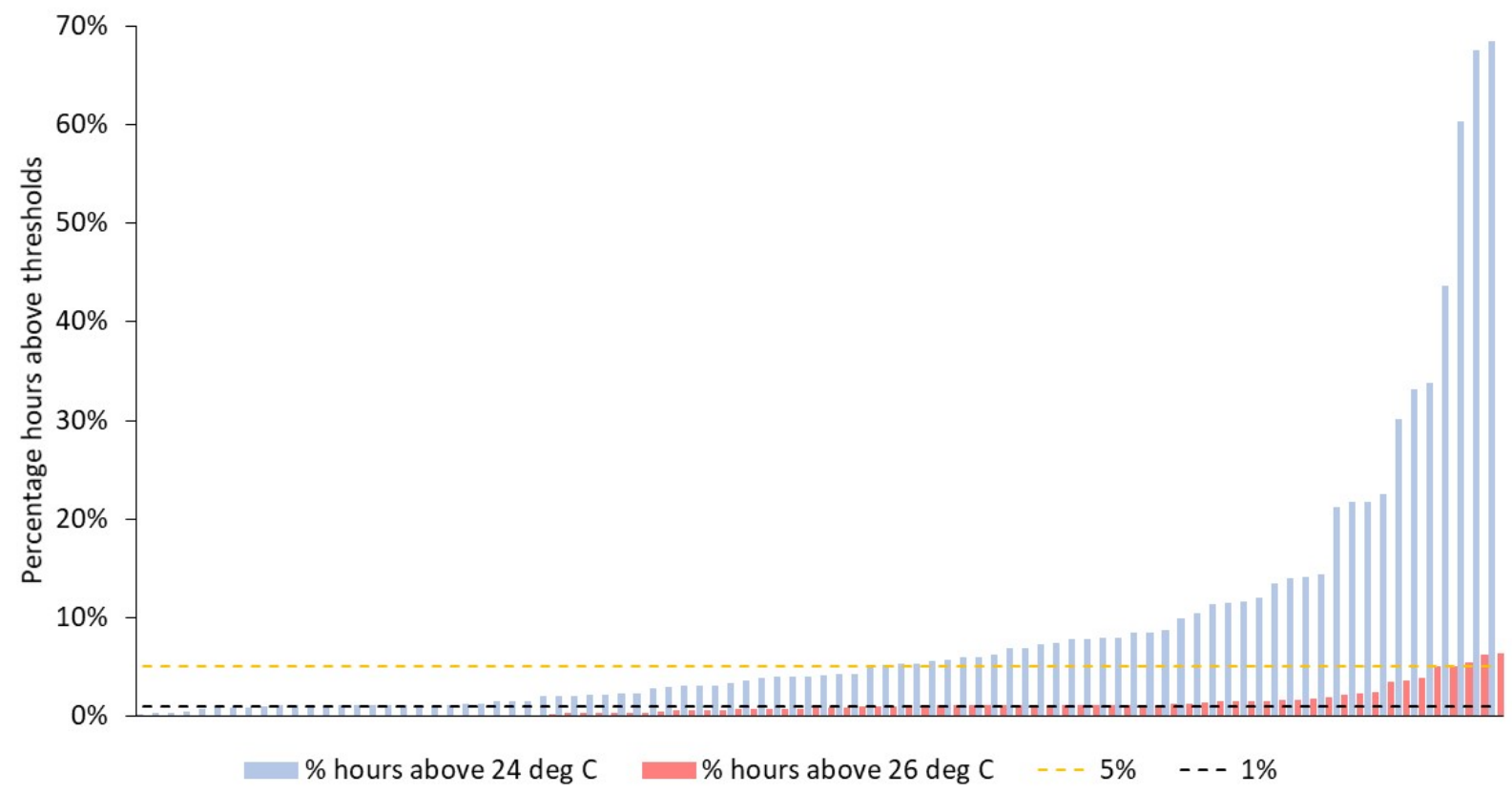

Figure 8 Percentage of occupied hours above static threshold temperatures by property for bedrooms, summer 2015 


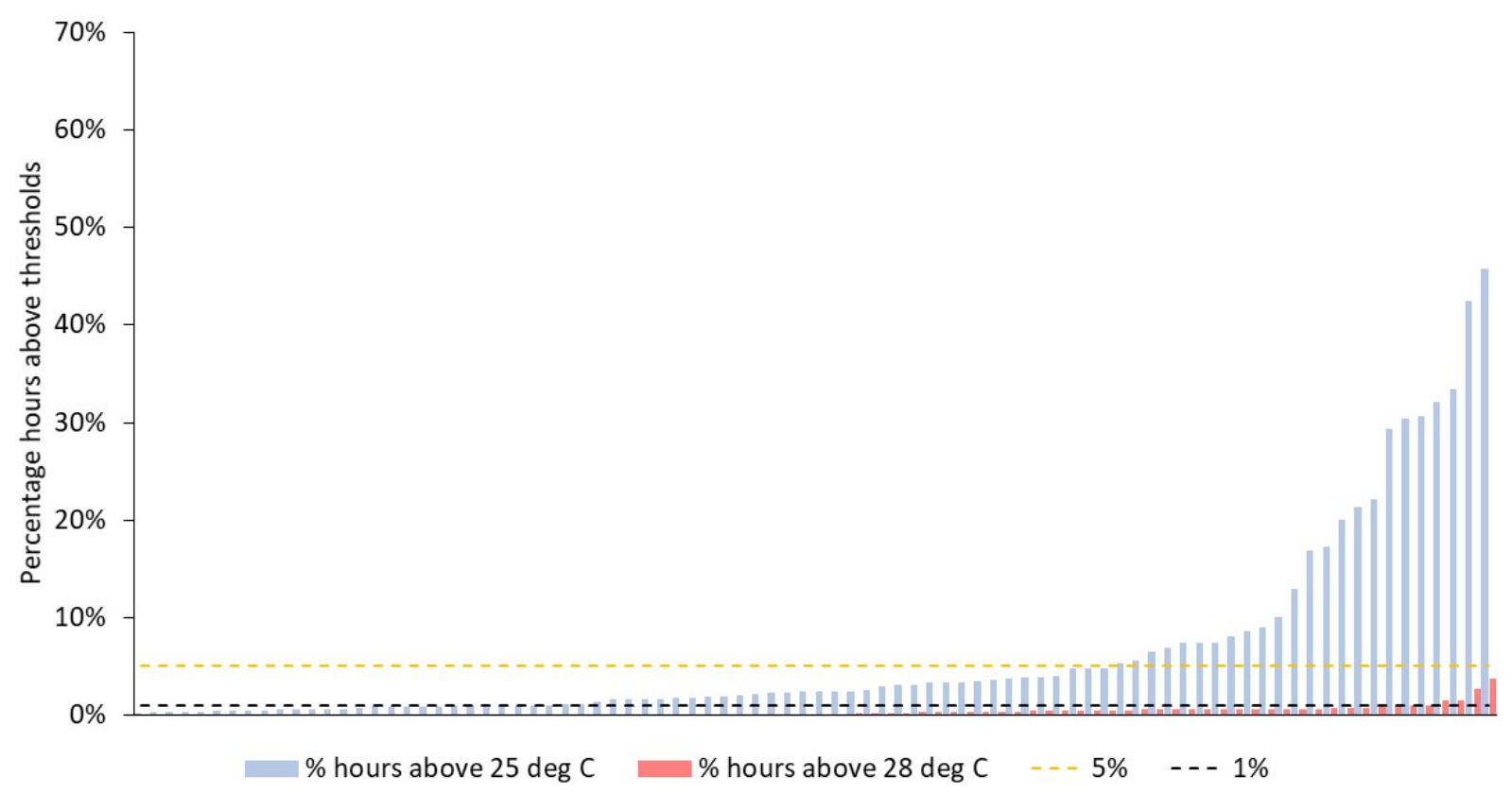

Figure 9 Percentage of occupied hours above static threshold temperatures by property for living rooms, summer 2015

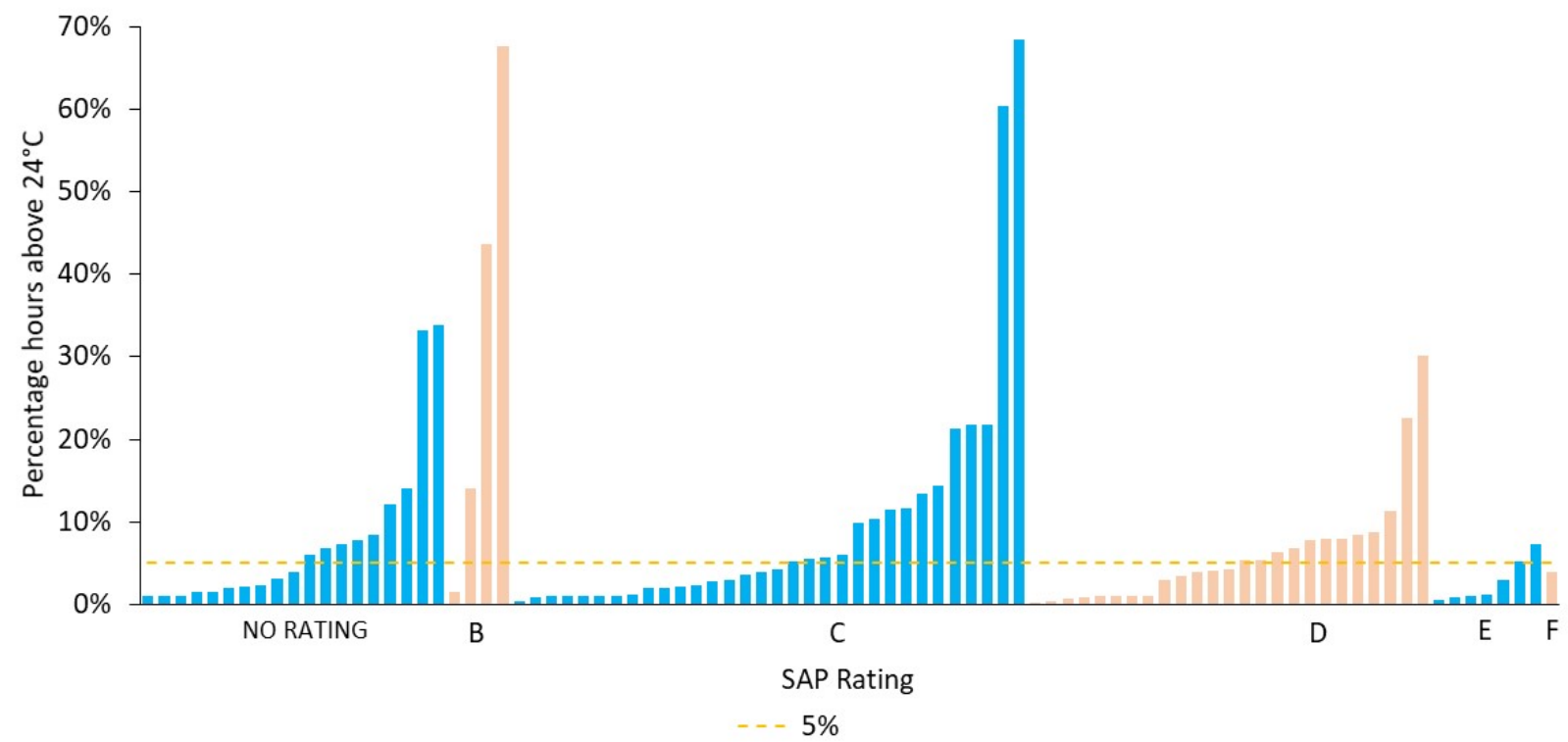

Figure 10 Percentage of occupied hours above $24^{\circ} \mathrm{C}$ by SAP rating and property for bedrooms, summer 2015 


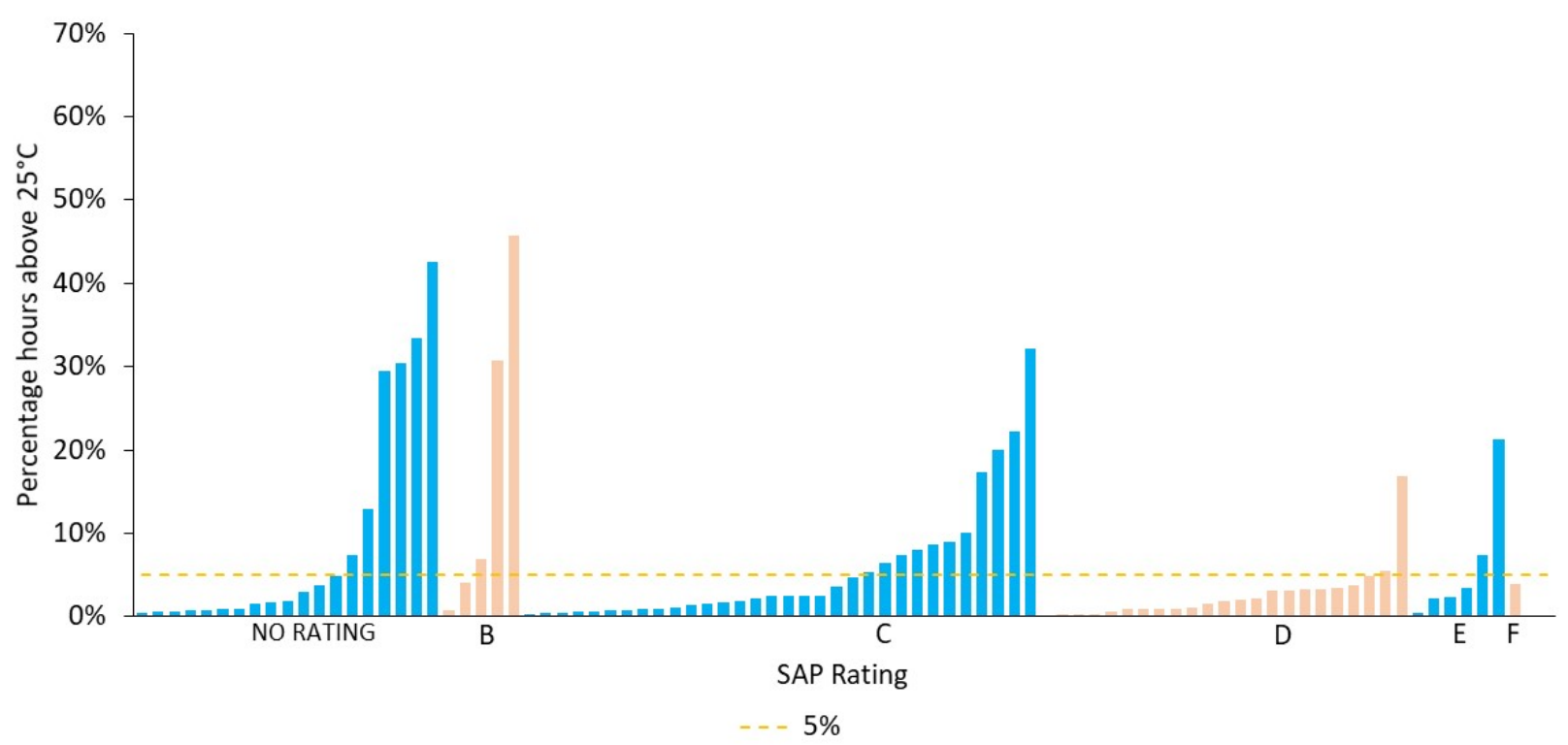

Figure 11 Percentage of occupied hours above $25^{\circ} \mathrm{C}$ by SAP rating and property for living rooms, summer 2015

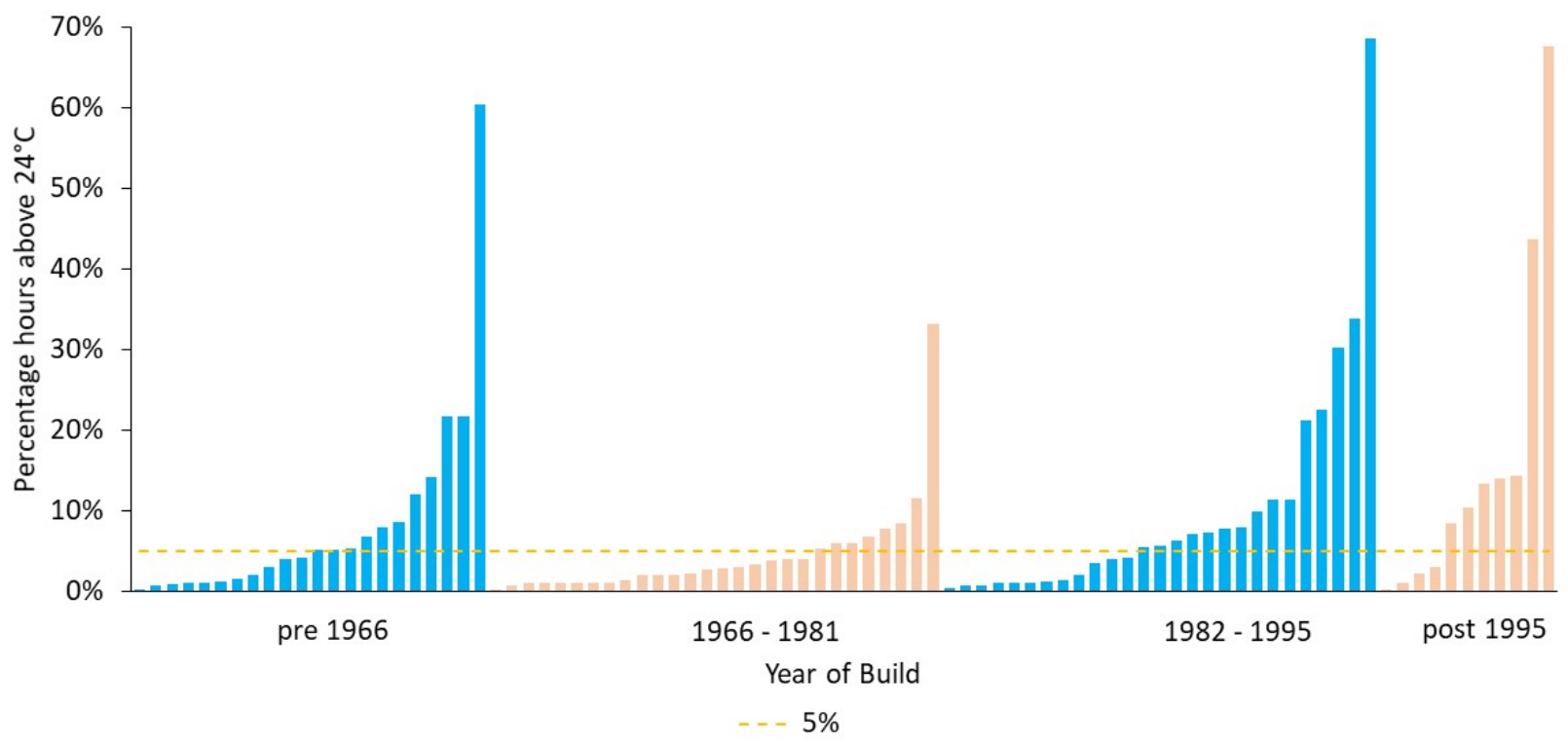

Figure 12 Percentage of occupied hours above $24^{\circ} \mathrm{C}$ by year of build and property for bedrooms, summer 2015 


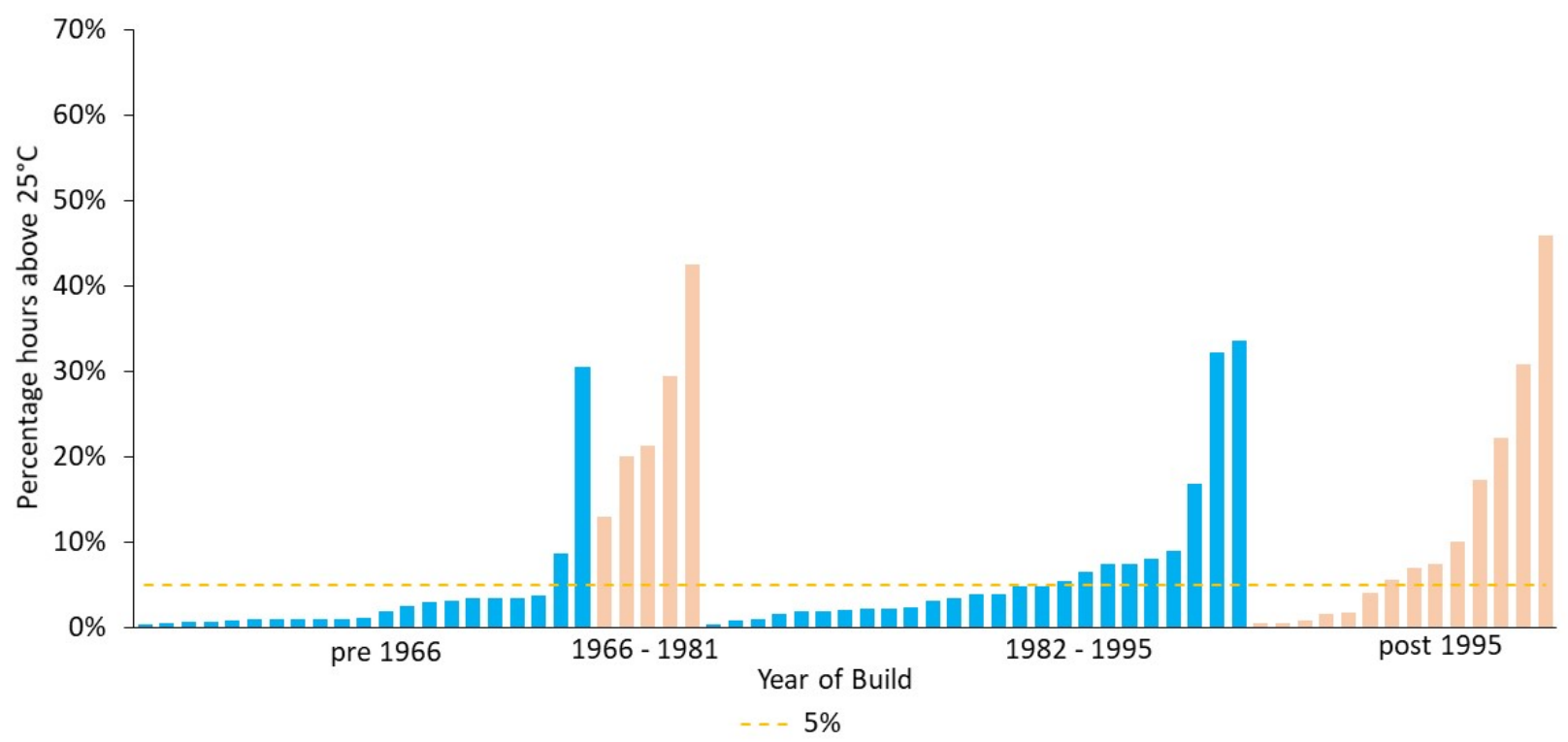

Figure 13 Percentage of occupied hours above $25^{\circ} \mathrm{C}$ by year of build and property for living rooms, summer 2015

\subsection{Whole sample}

During occupied hours, the mean bedroom and living room temperatures for summer 2015 across all properties were $21.2^{\circ} \mathrm{C}$ and $21.7^{\circ} \mathrm{C}$, respectively, significantly different at $\mathrm{p}<0.05$. The range of the mean bedroom temperature was from $17.7^{\circ} \mathrm{C}$ to $24.5^{\circ} \mathrm{C}$, and that for living rooms was from $17.7^{\circ} \mathrm{C}$ to $24.8^{\circ} \mathrm{C}$. Eight bedrooms and 12 living rooms exceeded a temperature of $30^{\circ} \mathrm{C}$. The maximum bedroom temperature during occupied hours for an individual property was $31.3^{\circ} \mathrm{C}$; this occurred within a detached house built in 1979 , with a filled cavity wall construction, but with no SAP rating, at 2300 hours on July $1^{\text {st }}$. The maximum living room temperature during occupied hours was $34.2^{\circ} \mathrm{C}$; this occurred within an E rated, end-terrace bungalow built in 1971 , with a filled cavity wall construction, at 2000 hours on June $30^{\text {th }}$. These maximum temperatures occurred during the short hot spell at the end of June and start of July where external temperatures peaked at $28.8^{\circ} \mathrm{C}$ on June $30^{\text {th }}$ and $33.3^{\circ} \mathrm{C}$ on July $1^{\text {st }}$.

$42 \%$ of bedrooms exceeded the $24^{\circ} \mathrm{C}(5 \%)$ overheating criteria, and $40 \%$ of bedrooms exceeded the $26^{\circ} \mathrm{C}(1 \%)$ criteria. $24 \%$ of living rooms exceeded the $25^{\circ} \mathrm{C}(5 \%)$ criteria, and $5 \%$ of living rooms exceeded the $28^{\circ} \mathrm{C}(1 \%)$ criteria. Performance against adaptive criteria is considered in Section 3.9.

\subsection{Property type}


Bedrooms in mid floor flats displayed a significantly higher mean temperature, at $22.1^{\circ} \mathrm{C}$, than the ground floor flat mean of $20.7^{\circ} \mathrm{C}$. For living rooms, top and mid floor flats displayed higher mean temperatures, at $22.1^{\circ} \mathrm{C}$ and $23.2^{\circ} \mathrm{C}$, respectively, than the ground floor flat mean of $21.5^{\circ} \mathrm{C}$, significantly so for mid floor flats. Significantly, houses exhibited the greatest percentages of properties exceeding the lower static overheating criteria for bedrooms, and bungalows, the least. Flats displayed a significantly higher percentage for exceedance of the $25^{\circ} \mathrm{C}$ (5\%) living room criteria. There were significantly lower percentages of bedrooms in ground floor flats which exceeded both the $24^{\circ} \mathrm{C}(5 \%)$ and $26^{\circ} \mathrm{C}(1 \%)$ criteria compared with mid and top floor flats.

\subsection{SAP rating}

It is noted that sample sizes for B and E rated properties were small (seven or under). Significantly, bedrooms in $B$ and $C$ rated properties showed higher mean temperatures than that for the $E$ rated category. The $B$ rated category displayed the highest percentage of properties exceeding each of the four static overheating criteria, although this was not statistically significant. Living rooms for $D$ rated properties significantly showed the lowest percentage of exceedance, at $7 \%$, against the $25^{\circ} \mathrm{C}(5 \%)$ criteria.

\subsection{Year of build}

Bedrooms and living rooms in properties built after 1995 showed the highest mean temperatures of $22.3^{\circ} \mathrm{C}$ and $22.5^{\circ} \mathrm{C}$, respectively. Properties in the $1966-1981$ range displayed the lowest means for both bedrooms and living rooms, significantly so compared with all other ranges for bedrooms. The picture for overheating with year of build has no obvious trend. The 1966 - 1981 category displayed significantly lower percentages of properties above the $26^{\circ} \mathrm{C}(1 \%)$ bedroom and $25^{\circ} \mathrm{C}(5 \%)$ living room thresholds, at $11 \%$ and $14 \%$, respectively. $85 \%$ of properties in the 1982 - 1995 category exceeded the $25^{\circ} \mathrm{C}(5 \%)$ living room threshold, a significant result.

\subsection{Wall construction}

$86 \%$ of the final data set properties possessed filled wall cavities, and sample size numbers for the remaining wall constructions were low. Therefore, it is difficult to draw any conclusions about differences in summary values. The single timber frame property showed the highest mean living room temperature when compared with other wall constructions, at $24.8^{\circ} \mathrm{C}$ and exhibited the highest percentage of exceedance hours, at $46 \%$, above the $25^{\circ} \mathrm{C}(5 \%)$ living room threshold, although this was not statistically significant.

\subsection{Built form}


The built form category comprises data for houses and bungalows. Living rooms in end terrace properties displayed a significantly higher mean temperature than that for detached and mid terrace properties. Significantly, end terrace properties were subject to overheating against static criteria; $61 \%$ of bedrooms in end terrace properties exceeded the $26^{\circ} \mathrm{C}(1 \%)$ threshold. A small number of end terrace properties exhibited particularly high percentages of exceedance hours; three bedrooms demonstrated over $40 \%$ exceedance hours above $24^{\circ} \mathrm{C}$ and four living rooms showed over $20 \%$ exceedance hours above $25^{\circ} \mathrm{C}$.

\subsection{Overheating against adaptive criteria}

Results relate to the occupied hours for the period June $1^{\text {st }}$ to August $31^{\text {st }}$, with the exception of the TM59 Criterion (b) for bedrooms which is based on annual hours. TM52 requires a failure for at least two out of the three criteria for a room to fail overall, and only a single bedroom (1.0\%) and two living rooms $(2.0 \%)$ demonstrated this. Bedroom failures against the individual Criteria 1, 2 and 3 numbered zero, eight (8.2\%) and one (1.0\%), respectively. Living room failures against Criteria 1, 2 and 3 numbered one (1.0\%), $27(27.0 \%)$ and two $(2.0 \%)$, respectively. Within these failures, trends by property category were not particularly apparent, not least because of the low number of failures. However, of the 27 Criterion 2 living room failures, $48 \%$ were bungalows, $82 \%$ were constructed after 1981, and four of the six flat failures occurred in top floor flats.

TM59 requires that living rooms pass TM59 Criterion (a), which is identical to TM52 Criterion 1 , and that bedrooms additionally pass TM59 Criterion (b). There was a single living room failure against TM59 and five (5\%) bedroom failures; the bedrooms all failed TM59 criterion (b) only, the static component. No rooms in flats failed against adaptive criteria, although one bedroom in a flat failed against the TM59 static Criterion (b).

\section{Discussion}

The overall mean living room temperature, at $21.7^{\circ} \mathrm{C}$, was $0.5^{\circ} \mathrm{C}$ higher than that for bedrooms, a result significant at the $p<0.05$ level. This is a greater difference than that found by Beizaee et al. (2013) and McGill et al. (2017) where the mean bedroom temperature exceeded the mean living room temperature by $0.2^{\circ} \mathrm{C}$ for both studies. Other studies have found the overall mean living room temperature to be $0.2^{\circ} \mathrm{C}$ or $0.3^{\circ} \mathrm{C}$ lower than the mean bedroom temperature (Lomas \& Kane, 2013), (Mavrogianni et al., 2017), (DECC, 2013). Flats displayed a significantly higher percentage for exceedance of the $25^{\circ} \mathrm{C}(5 \%)$ living room criteria which is consistent with Lomas \& Kane (2013). Overall, bedrooms showed a higher tendency to exceed static overheating criteria than living rooms; the threshold temperatures are relatively lower for bedrooms. When compared with 
the corresponding values of other surveys (Table 1), the mean temperatures and percentage of rooms exceeding the static overheating criteria in this study lie within the same range but are generally on the low side. Differences between survey locations, monitoring periods, external temperatures and sample composition would be expected to affect results.

There was a tendency for SAP B rated properties to be warmer, and bedrooms in B and C rated properties showed significantly higher mean temperatures than that for the E rated category. This is pertinent given that The Clean Growth Strategy for the UK includes the ambition for homes experiencing fuel poverty to improve to a SAP rating of band C by 2030 (HM Government, 2017). It is also noted that within a survey of 823 English dwellings, households with SAP points greater than 70 , (corresponding to the lower end of the $\mathrm{C}$ rated category) were more likely to report an overheating problem (DECC, 2013).

There were several instances where dwellings from later construction periods displayed significantly higher mean temperatures than those from earlier periods (Table A.1). Newer builds were found to be warmer by Beizaee et al. (2013), and newer builds exhibited temperatures above thresholds for longer than older builds (Pathan et al., 2017).

Regarding built form for houses and bungalows, bedrooms and living rooms in end terrace properties showed higher mean temperatures, along with a greater tendency to exceed static thresholds, the latter being significant at the $p<0.1$ level for the upper bedroom threshold. Beizaee et. al. (2013) reported that a higher proportion of bedrooms in end terrace properties were found to exhibit overheating against a $24^{\circ} \mathrm{C}(5 \%)$ threshold than other built forms.

Although there are few rooms failing against TM52 or TM59 overall, there are considerable percentages of rooms experiencing temperatures above static thresholds during summer 2015, particularly in the case of bedrooms where $40 \%$ exceeded the $26^{\circ} \mathrm{C}(1 \%)$ criteria. TM59 Criterion (b) for bedrooms does not account for the duration of periods above $26^{\circ} \mathrm{C}$ and does not consider longer periods which may cause heat stress to occupants. There were two living rooms with over $40 \%$ of summer hours above $25^{\circ} \mathrm{C}$, and $27 \%$ of living rooms failed against Criterion 2 of TM52, also indicating potential thermal discomfort. The low proportion of rooms failing against adaptive methods compared with static methods is in agreement with Beizaee et al. (2013), Lomas \& Kane (2013) and Vellei et al. (2017) where fewer properties overheated against adaptive criteria compared with static thresholds. Higher levels of overheating against adaptive criteria have been reported for low energy 
builds; 44\% of social housing Passivhaus flats overheated against TM52 (Tabatabaei Sameni et al., 2015), and 30\% of living rooms in low energy new builds exceeded TM52 Criterion 1 (McGill et al., 2017).

The disparity between static and adaptive results suggest further improvements to the assessment of overheating is warranted. Account could be taken of the duration and severity of continuous periods of overheating as proposed by Lee \& Steemers (2017). The work of Tabatabaei Sameni et al., (2015) concerning the effect of the weighting factor within the daily exceedance limit of TM52 Criterion 2 is also pertinent. With overheating performance affecting the design of new builds, the retrofit of existing dwellings, and the housing of vulnerable occupants, effective assessment is important.

One implication of this work is that vulnerable occupant groups who may be particularly affected by heat may need to be housed on the ground floor; the need to take into account the vulnerability of occupants with respect to overheating when housing has been highlighted previously (Tabatabaei Sameni et al., 2015). As well as vulnerability to overheating due to fragile health, occupants may be more prone to overheating where ventilation control is limited by impaired mobility (Vellei et al., 2017) or where there are security concerns relating to opening windows (Mavrogianni et al., 2017). Consequently, social housing should provide accessible ventilation methods and secure window openings as required. Additionally, since the Government aims to introduce a Future Homes Standard by 2025, which would require new homes to be built with "world class" levels of energy efficiency (HM Government, 2019), any future policy should also include measures to mitigate overheating in such builds (these might be expected to involve ventilation, external shading, building orientation and glazing).

\section{Limitations}

Several of the property categories for the current study have a small sample size. With larger representation, the relationship between internal temperature and category variables may be more apparent. There was no sustained period of consistently high temperatures for which overheating could be assessed; such a period may have further illustrated differences between property categories, although this area may be problematic in general, even with the relatively large sample here, due to the many types of property. There are several areas where additional information was not available which could have aided the explanation of results, particularly for the individual properties which exhibited high percentages of exceedance hours above overheating 
thresholds, e.g. data on occupancy behaviour, particularly regarding ventilation and occupied hours, SAP ratings for all properties, room orientation and the extent of internal and external shading. For assessment, the monitoring period of June $1^{\text {st }}$ to August $31^{\text {st }}$ was considered rather than an annual or May to September period, and occupied hours were assumed. There was no exact record of sensor location, although a subsequent calibration exercise was undertaken.

\section{Conclusions}

This study provides empirically based internal temperature measurements and overheating analysis for a relatively large sample of 122 free-running social housing properties located in central England, thus providing a reference point for researchers and social housing providers. Established methods of assessment, namely CIBSE static criteria and the adaptive TM52 method, were supplemented by the more recent TM59 guidance to assess overheating risk in dwellings. A robust data cleaning process was employed which included a new "delta lag" visual method to identify and remove erroneous indoor air temperature data. In an original application, overheating analysis was performed by SAP rating. The key findings are:

- $42 \%$ of bedrooms exceeded the $24^{\circ} \mathrm{C}(5 \%)$ criteria, and $40 \%$ of bedrooms exceeded the $26^{\circ} \mathrm{C}(1 \%)$ criteria. $24 \%$ of living rooms exceeded the $25^{\circ} \mathrm{C}(5 \%)$ criteria, and $5 \%$ of living rooms exceeded the $28^{\circ} \mathrm{C}$ (1\%) criteria. Higher proportions of bedrooms exceeded static overheating thresholds.

- Very few properties exceeded the criteria for thermal comfort adaptive methods.

- The mean living room temperature was significantly higher, by $0.5^{\circ} \mathrm{C}$, than that for bedrooms,

- Bedrooms and living rooms in mid and top floor flats exhibited higher mean temperatures than those in houses and bungalows. Bedrooms in ground floor flats were significantly less likely to overheat than those in mid and top floor flats.

- Bedrooms and living rooms in SAP B rated properties (the highest rating within this study) exhibited the highest mean temperatures and the highest number of hours above overheating thresholds. Further investigation into the relationship between SAP category and overheating is recommended.

- Bedrooms and living rooms in properties constructed after 1995 exhibited the highest mean temperatures. 
- Bedrooms and living rooms in end terrace properties exhibited higher mean temperatures than those in other (non-flat) forms, with bedrooms significantly displaying the highest percentage exceeding overheating the upper static threshold. This is surprising and may be due to a few rooms exhibiting a particularly high proportion of exceedance hours.

Although the monitoring period occurred throughout a summer with slightly lower than average temperatures which contained no prolonged period of high outdoor temperatures, overheating was apparent against static thresholds, particularly in bedrooms. Few rooms failed against adaptive criteria, thus highlighting a disparity between static and adaptive methods. The presented sample is reasonably representative of the English housing stock. With a predicted increase in hot summers (Met Office, 2019c), as experienced in 2018, these results suggest that a large proportion of the English Midlands housing stock might be expected to overheat significantly in future years, at least according to static criteria.

\section{Acknowledgements}

The authors would like to thank Mr Robert Stevens for performing overheating risk analysis using TM52 and TM59 as a part of his MSc dissertation. The provision of internal temperature data and property information by $\mathrm{EMH}$ homes is also gratefully acknowledged. The research would not have been possible without the cooperation of the many households who kindly participated in this study.

\section{References}

Adekunle, T.O., Nikolopoulou, M. 2016, "Thermal comfort, summertime temperatures and overheating in prefabricated timber housing", Building and Environment, vol. 103, pp. 21-35 https://doi.org/10.1016/j.buildenv.2016.04.001

ASHRAE 2002, ASHRAE guideline 14-2002: Measurement of energy and demand savings. Atlanta, GA, American Society of Heating, Refrigerating and Air-conditioning Engineers.

Baborska-Narożny, M., Stevenson, F. \& Grudzińska, M. 2017, "Overheating in retrofitted flats: occupant practices, learning and interventions", Building Research \& Information, vol. 45, no. 1-2, pp. 40-59 https://doi.org/10.1080/09613218.2016.1226671

Beizaee, A., Lomas, K.J. \& Firth, S.K. 2013, "National survey of summertime temperatures and overheating risk in English homes", Building and Environment, vol. 65, pp. 1-17. https://doi.org/10.1016/j.buildenv.2013.03.011

CIBSE 2013, TM52: The limits of thermal comfort: avoiding overheating in European Buildings. London: Chartered Institution of Building Services Engineers.

CIBSE 2015, Guide A, Environmental design. 8th ed. London: Chartered Institution of Building Services Engineers. 
CIBSE 2017, TM59: 2017 Design methodology for the assessment of overheating risk in homes. London: Chartered Institution of Building Services Engineers.

DCLG 2012, Department for Communities and Local Government Investigation into Overheating in Homes: Literature Review. Available online at: https://www.gov.uk/government/publications/investigation-intooverheating-in-homes [Accessed 12.05.19]

DECC 2012, SAP 2012 The Government's Standard Assessment Procedure for Energy Rating of Dwellings 2012 edition. Watford: BRE. Available online at: https://www.bre.co.uk/filelibrary/SAP/2012/SAP-2012_9-92.pdf [Accessed 20.12.19]

DECC 2013, Report 7: Thermal comfort \& overheating. Department of Energy and Climate Change December 2013. Available online at:

https://assets.publishing.service.gov.uk/government/uploads/system/uploads/attachment_data/file/414600/ 7_Thermal_comfort.pdf [Accessed 12.05.19]

Fletcher, M.J., Johnston, D.K., Glew, D.W., Parker, J.M. 2017, “An empirical evaluation of temporal overheating in an assisted living Passivhaus dwelling in the UK", Building and Environment, vol. 121, pp. 106-118 https://doi.org/10.1016/j.buildenv.2017.05.024

Fosas, D., Coley, D.A., Natarajan, S., Herrera, M., Fosas de Pando, M. \& Ramallo-Gonzalez, A. 2018, "Mitigation versus adaptation: Does insulating dwellings increase overheating risk?", Building and Environment, vol. 143, pp. 740-759. https://doi.org/10.1016/j.buildenv.2018.07.033

Gupta, R. \& Gregg, M. 2018, "Assessing energy use and overheating risk in net zero energy dwellings in UK", Energy \& Buildings, vol. 158, pp. 897-905. https://doi.org/10.1016/j.enbuild.2017.10.061

Hamdy, M., Carlucci, S., Hoes, P-J., Hensen, J.L.M. 2017, "The impact of climate change on the overheating risk in dwellings-A Dutch case study", Building and Environment, vol. 122, pp. 307-323 https://doi.org/10.1016/j.buildenv.2017.06.031

HM Government 2016. The Building Regulations 2010: L1A Conservation of fuel and power in new dwellings. 2013 edition incorporating 2016 amendments - for use in England.

HM Government 2017. The Clean Growth Strategy, Leading the way to a low carbon future. Available from: https://www.gov.uk/government/publications/clean-growth-strategy [Accessed 15.12.12]

HM Government 2019. Spring Statement 2019: Written Ministerial Statement. Available from: https://assets.publishing.service.gov.uk/government/uploads/system/uploads/attachment_data/file/785618/ WMS_final_Commons.pdf [Accessed 15.12.12]

Lee, W.V. \& Steemers, K. 2017, "Exposure duration in overheating assessments: a retrofit modelling study", Building Research \& Information, vol. 45, no. 1-2, pp. 60-82. https://doi.org/10.1080/09613218.2017.1252614

Lomas, K.J. \& Kane, T. 2013, "Summertime temperatures and thermal comfort in UK homes", Building Research \& Information, vol. 41, no. 3, pp. 259-280. https://doi.org/10.1080/09613218.2013.757886

Lomas, K.J. \& Porritt, S.M. 2017, "Overheating in buildings: lessons from research", Building Research \& Information, vol. 45, no. 1-2, pp. 1-18. https://doi.org/10.1080/09613218.2017.1256136

Mavrogianni, A., Wilkinson, P., Davies, M., Biddulph, P., \& Oikonomou, E. 2012, "Building characteristics as determinants of propensity to high indoor summer temperatures in London dwellings ", Building \& Environment, vol. 55, pp. 117-130. https://doi.org/10.1016/j.buildenv.2011.12.003 
Mavrogianni, A., Taylor, J., Davies, M., Thoua, C., \& Kolm-Murray, J. 2015, "Urban social housing resilience to excess summer heat", Building Research \& Information, vol. 43, no. 3, pp. 316-333.

https://doi.org/10.1080/09613218.2015.991515

Mavrogianni, A., Pathan, A., Oikonomou, E., Biddulph, P., Symonds, P. \& Davies, M. 2017, "Inhabitant actions and summer overheating risk in London dwellings", Building Research \& Information, vol. 45, no. 1-2, pp. 119142. https://doi.org/10.1080/09613218.2016.1208431

McGill, G., Sharpe, T., Robertson, L., Gupta, R. \& Mawditt, I. 2017, "Meta-analysis of indoor temperatures in new-build housing", Building Research \& Information, vol. 45, no. 1-2, pp. 19-39.

https://doi.org/10.1080/09613218.2016.1226610

Met Office 2006a, MIDAS: UK Hourly Weather Observation Data. NCAS British Atmospheric Data Centre. Available online at: http://catalogue.ceda.ac.uk/uuid/916ac4bbc46f7685ae9a5e10451bae7c [Accessed 14.03.19]

Met Office 2006b, MIDAS: Global Radiation Observations. NCAS British Atmospheric Data Centre. Available online at: http://catalogue.ceda.ac.uk/uuid/b4c028814a666a651f52f2b37a97c7c7 [Accessed 14.03.19]

Met Office 2019a UK and regional series. Available online at:

https://www.metoffice.gov.uk/research/climate/maps-and-data/uk-and-regional-series [Accessed 15.10.19]

Met Office 2019b MIDAS Open: UK daily weather observation data, v201908. Centre for Environmental Data Analysis, 30 October 2019. http://dx.doi.org/10.5285/6ad6792f44c84c228651b01d182d9d73 [Accessed 18.12.19]

Met Office 2019c UK Climate Projections: Headline Findings, September 2019 Version 2. Available online at: https://www.metoffice.gov.uk/binaries/content/assets/metofficegovuk/pdf/research/ukcp/ukcp-headlinefindings-v2.pdf [Accessed 05.12.19]

MHCLG 2019a Ministry of Housing, Communities \& Local Government. English Housing Survey Headline Report, 2017-18. Available online at: https://www.gov.uk/government/statistics/english-housing-survey-2017to-2018-headline-report [Accessed 15.12.19]

MHCLG 2019b Ministry of Housing, Communities \& Local Government. English Housing Survey Social rented sector, 2017-18. Available online at: https://www.gov.uk/government/statistics/english-housing-survey-2017to-2018-social-rented-sector [Accessed 15.12.19]

MHCLG 2019c, Statistical data set: Stock profile. Ministry of Housing, Communities \& Local Government. Available online at: https://www.gov.uk/government/statistical-data-sets/stock-profile [Accessed 15.10.19]

Morgan, C., Foster, J.A., Poston, A. \& Sharpe, T.R. 2017, "Overheating in Scotland: contributing factors in occupied homes", Building Research \& Information, vol. 45, no. 1-2, pp. 143-156 https://doi.org/10.1080/09613218.2017.1241472

Oikonomou, E., Davies, M., Mavrogianni, A., Biddulph, P., Wilkinson, P. \& Kolokotroni, M. 2012, "Modelling the relative importance of the urban heat island and the thermal quality of dwellings for overheating in London", Building and Environment, vol. 57, pp. 223-238. https://doi.org/10.1016/j.buildenv.2012.04.002

Onset 2019, Onset HOBO data loggers. Onset Computer Corporation. Available online at: https://www.onsetcomp.com [Accessed 12.12.19]

Orsis 2019, Orsis CO2SS Combined Temperature, Humidity \& CO2 Sensor. Available online at: https://www.orsis.co.uk/products/co2ss/ [Accessed 15.10.19] 
Pathan, A., Mavrogianni, A., Summerfield, A., Oreszczyn, T. \& Davies, M. 2017, "Monitoring summer indoor overheating in the London housing stock", Energy \& Buildings, vol. 141, pp. 361-378.

https://doi.org/10.1016/j.enbuild.2017.02.049

Peacock, A.D., Jenkins, D.P. \& Kane, D. 2010, "Investigating the potential of overheating in UK dwellings as a consequence of extant climate change", Energy Policy, vol. 38, no. 7, pp. 3277-3288.

https://doi.org/10.1016/j.enpol.2010.01.021

PHE 2018, Public Health England PHE heatwave mortality monitoring: Summer 2018. Available online at: https://www.gov.uk/government/publications/phe-heatwave-mortality-monitoring [Accessed on 13.12.19]

Porritt, S.M., Cropper, P.C., Shao, L. \& Goodier, C.I. 2012, "Ranking of interventions to reduce dwelling overheating during heat waves", Energy \& Buildings, vol. 55, pp. 16-27

https://doi.org/10.1016/j.enbuild.2012.01.043

Symonds, P., Taylor, J., Mavrogianni, A., Davies, M., Shrubsole, C., Hamilton, I. \& Chalabi, Z. 2017, "Overheating in English dwellings: comparing modelled and monitored large-scale datasets", Building Research \& Information, vol. 45, no. 1-2, pp. 195-208. https://doi.org/10.1080/09613218.2016.1224675

Tabatabaei Sameni, S.M., Gaterell, M., Montazami, A. \& Ahmed, A. 2015, "Overheating investigation in UK social housing flats built to the Passivhaus standard", Building and Environment, vol. 92, pp. 222-235. https://doi.org/10.1016/j.buildenv.2015.03.030

Taylor, J., Davies, M., Mavrogianni, A., Chalabi, Z., Biddulph, P., Oikonomou, E., Das, P. \& Jones, B. 2014, "The relative importance of input weather data for indoor overheating risk assessment in dwellings", Building \& Environment, vol. 76, pp. 81-91.

https://doi.org/10.1016/j.buildenv.2014.03.010

The R Foundation 2018, The R Foundation for Statistical Computing R version 3.5.1 (2018-07-02). Available online at: https://cran.r-project.org/bin/windows/base/old/3.5.1/ [Accessed on 01.02.19]

Tink, V., Porritt, S., Allinson, D. \& Loveday, D. 2018, "Measuring and mitigating overheating risk in solid wall dwellings retrofitted with internal wall insulation", Building and Environment, vol. 141, pp. 247-261 https://doi.org/10.1016/j.buildenv.2018.05.062

van Hooff, T., Blocken, B., Hensen, J.L.M., Timmermans, H.J.P., 2015 Reprint of: “On the predicted effectiveness of climate adaptation measures for residential buildings", Building and Environment, vol. 83, pp 142-158

https://doi.org/10.1016/j.buildenv.2014.10.006

Vellei, M., Ramallo-González, A.P., Coley, D., Lee, J., Gabe-Thomas, E., Lovett, T. \& Natarajan, S. 2017, "Overheating in vulnerable and non-vulnerable households", Building Research \& Information, vol. 45, no. 1-2, pp. 102-118. https://doi.org/10.1080/09613218.2016.1222190

\section{Appendix}

Table A.1 Significance levels from two sample Welch t-tests performed between pairs of mean values from Tables 4 and 5. (Only results significant at the $p<0.1$ level and below are shown).

\begin{tabular}{llcc} 
& & BEDROOM & LIVING ROOM \\
\cline { 2 - 4 } & \multicolumn{1}{c}{ Comparison of means $^{\dagger}$} & $\mathrm{p}$ & $\mathrm{p}$ \\
\hline PROPERTY TYPE & House/Flat & $<0.05$ & \\
\hline SAP RATING & $\mathrm{C} / \mathrm{E}$ & $<0.05$ & \\
& $\underline{B} / \mathrm{E}$ & $<0.1$ & \\
\hline
\end{tabular}




\begin{tabular}{llll}
\hline YEAR OF BUILD & Pre 1966/1966-1981 & $<0.05$ & \\
\cline { 2 - 3 } & Pre 1966/1982-1995 & & $<0.05$ \\
& Pre 1966/Post 1995 & $<0.05$ & $<0.05$ \\
& $1966-1981 / 1982-1995$ & $<0.05$ \\
& $1966-1981 /$ Post 1995 & $<0.05$ & $<0.05$ \\
\hline FLAT LEVEL & Ground/Mid floor & $<0.05$ & $<0.1$ \\
\hline BUILT FORM & Mid/Top floor & $<0.1$ & $<0.1$ \\
& End terrace/Detached & & $<0.05$ \\
\hline
\end{tabular}

${ }^{\dagger}$ The category variable with the highest mean is underlined. Where significance is given for both bedroom and living room, the underlined variable has the highest mean for both rooms.

Table A.2 Bedrooms exceeding $5 \%$ and $1 \%$ occupied hours for $24^{\circ} \mathrm{C}$ and $26^{\circ} \mathrm{C}$. ${ }^{*}$ Significant at $\mathrm{p}<0.05, * *$ significant at $\mathrm{p}<0.1$.

\begin{tabular}{|c|c|c|c|c|c|}
\hline BEDROOM & $\mathrm{n}$ & 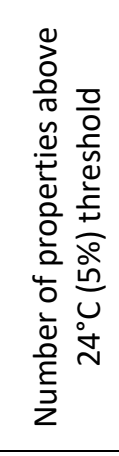 & 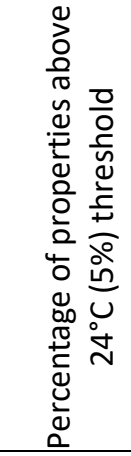 & 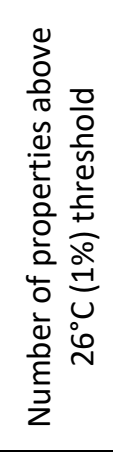 & 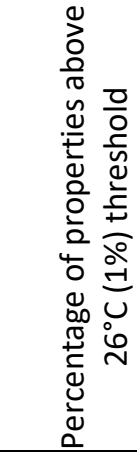 \\
\hline ALL PROPERTIES & 98 & 41 & $42 \%$ & 39 & $40 \%$ \\
\hline \multicolumn{6}{|l|}{ PROPERTY TYPE } \\
\hline House & 45 & $24 * *$ & $53 \% * *$ & 21 & $47 \%$ \\
\hline Bungalow & 27 & $6^{*}$ & $22 \% *$ & 9 & $33 \%$ \\
\hline Flat & 26 & 11 & $42 \%$ & 9 & $35 \%$ \\
\hline \multicolumn{6}{|l|}{ SAP RATING } \\
\hline B & 4 & 3 & $75 \%$ & 3 & $75 \%$ \\
\hline C & 34 & 15 & $44 \%$ & 15 & $44 \%$ \\
\hline D & 29 & 12 & $41 \%$ & 11 & $38 \%$ \\
\hline$E$ & 7 & 2 & $29 \%$ & 3 & $43 \%$ \\
\hline$F$ & 1 & 0 & $0 \%$ & 1 & $100 \%$ \\
\hline No SAP rating & 23 & 9 & $39 \%$ & 7 & $30 \%$ \\
\hline \multicolumn{6}{|l|}{ YEAR OF BUILD } \\
\hline pre 1966 & 22 & 11 & $50 \%$ & $12^{*}$ & $55 \% *$ \\
\hline 1966 - 1981 & 36 & 26 & $72 \%$ & $4^{*}$ & $11 \% *$ \\
\hline 1982- 1995 & 29 & 15 & $52 \%$ & 12 & $41 \%$ \\
\hline post 1995 & 11 & 7 & $64 \%$ & 6 & $55 \%$ \\
\hline \multicolumn{6}{|c|}{ WALL CONSTRUCTION } \\
\hline Filled cavity & 84 & 34 & $40 \%$ & 52 & $62 \%$ \\
\hline Unfilled cavity & 7 & 3 & $43 \%$ & 3 & $43 \%$ \\
\hline
\end{tabular}




\begin{tabular}{lccccc} 
Solid - Uninsulated & 2 & 1 & $50 \%$ & 1 & $50 \%$ \\
$\begin{array}{l}\text { Solid - Insulated } \\
\text { Timber frame }\end{array}$ & 5 & 3 & $60 \%$ & 1 & $20 \%$ \\
\hline $\begin{array}{l}\text { FLAT LEVEL } \\
\text { Ground floor }\end{array}$ & 0 & & & & \\
Mid floor & 14 & $3^{* *}$ & $21 \% * *$ & $2 * *$ & $14 \% * *$ \\
Top floor & 6 & 4 & $67 \%$ & 3 & $50 \%$ \\
\hline BUILT FORM & 6 & 4 & $67 \%$ & 4 & $67 \%$ \\
$\begin{array}{l}\text { Detached } \\
\text { End terrace }\end{array}$ & 3 & 1 & $33 \%$ & 1 & $33 \%$ \\
Mid terrace & 18 & 9 & $50 \%$ & $11^{* *}$ & $61 \% * *$ \\
Semi & 18 & 7 & $39 \%$ & 7 & $39 \%$ \\
${ }^{\dagger}$ Other & 29 & 11 & $38 \%$ & 11 & $38 \%$ \\
${ }^{\dagger}$ Other' refers to mid terrace properties with 3 stories, mid terrace properties with an offset, or terrace \\
properties with an unknown position.
\end{tabular}

Table A.3 Living rooms exceeding $5 \%$ and $1 \%$ occupied hours for $25^{\circ} \mathrm{C}$ and $28^{\circ} \mathrm{C}$. ${ }^{*}$ Significant at $p<0.05$, $* *$ significant at $\mathrm{p}<0.1$.

\begin{tabular}{|c|c|c|c|c|c|}
\hline LIVING ROOM & $\mathrm{n}$ & 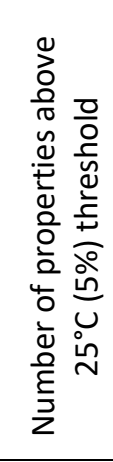 & 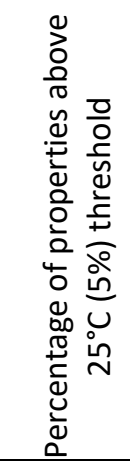 & 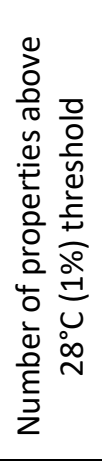 & 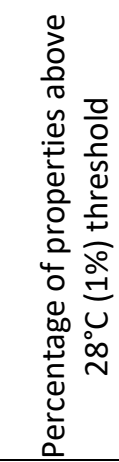 \\
\hline ALL PROPERTIES & 100 & 24 & $24 \%$ & 5 & $5 \%$ \\
\hline \multicolumn{6}{|l|}{ PROPERTY TYPE } \\
\hline House & 42 & 7 & $17 \%$ & 2 & $5 \%$ \\
\hline Bungalow & 32 & 7 & $22 \%$ & 3 & $9 \%$ \\
\hline Flat & 26 & $10 * *$ & $38 \% * *$ & 0 & $0 \%$ \\
\hline \multicolumn{6}{|l|}{ SAP RATING } \\
\hline B & 6 & 3 & $50 \%$ & 1 & $17 \%$ \\
\hline C & 36 & 11 & $31 \%$ & 1 & $3 \%$ \\
\hline D & 28 & $2 *$ & $7 \% *$ & 0 & $0 \%$ \\
\hline $\mathrm{E}$ & 6 & 2 & $33 \%$ & 1 & $17 \%$ \\
\hline $\mathrm{F}$ & 1 & 0 & $0 \%$ & 0 & $0 \%$ \\
\hline No SAP rating & 23 & 6 & $26 \%$ & 2 & $9 \%$ \\
\hline \multicolumn{6}{|l|}{ YEAR OF BUILD } \\
\hline pre 1966 & 22 & 11 & $50 \%$ & 0 & $0 \%$ \\
\hline $1966-1981$ & 37 & $5 *$ & $14 \% *$ & 2 & $5 \%$ \\
\hline 1982- 1995 & 26 & $22 *$ & $85 \% *$ & 1 & $4 \%$ \\
\hline post 1995 & 15 & 8 & $53 \%$ & 2 & $13 \%$ \\
\hline \multicolumn{6}{|c|}{ WALL CONSTRUCTION } \\
\hline Filled cavity & 85 & 20 & $24 \%$ & 3 & $4 \%$ \\
\hline Unfilled cavity & 8 & 2 & $25 \%$ & 0 & $0 \%$ \\
\hline Solid - Uninsulated & 2 & 0 & $0 \%$ & 0 & $0 \%$ \\
\hline Solid - Insulated & 4 & 1 & $25 \%$ & 1 & $25 \%$ \\
\hline Timber frame & 1 & 1 & $100 \%$ & 1 & $100 \%$ \\
\hline
\end{tabular}

FLAT LEVEL 


\begin{tabular}{lccccc} 
Ground floor & 13 & 3 & $23 \%$ & 0 & $0 \%$ \\
Mid floor & 5 & 4 & $80 \%$ & 0 & $0 \%$ \\
Top floor & 8 & 3 & $38 \%$ & 0 & $0 \%$ \\
\hline BUILT FORM & 4 & 0 & $0 \%$ & 0 & $0 \%$ \\
Detached & 17 & 6 & $35 \%$ & 3 & $18 \%$ \\
End terrace & 17 & 1 & $6 \%$ & 0 & $0 \%$ \\
Mid terrace & 33 & 7 & $21 \%$ & 2 & $6 \%$ \\
Semi & 3 & 0 & $0 \%$ & 0 & $0 \%$ \\
${ }^{+}$Other & & 0
\end{tabular}

‘'Other' refers to mid terrace properties with 3 stories, mid terrace properties with an offset, or terrace properties with an unknown position. 